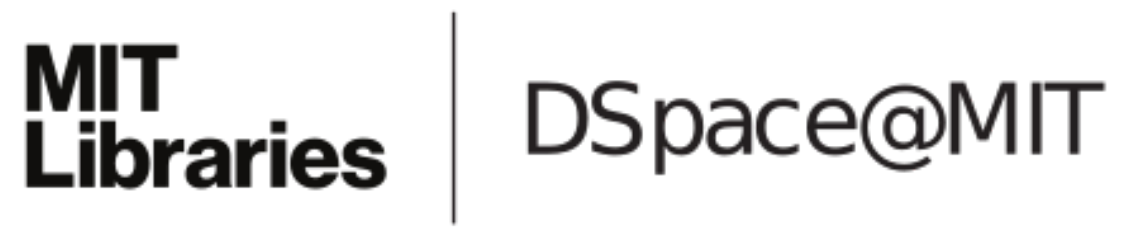

\author{
MIT Open Access Articles
}

Where do firms manage earnings?

The MIT Faculty has made this article openly available. Please share how this access benefits you. Your story matters.

Citation: Dyreng, Scott D., Michelle Hanlon, and Edward L. Maydew. "Where Do Firms Manage Earnings?" Review of Accounting Studies 17.3 (2012): 649-687. Web.

As Published: http://dx.doi.org/ 10.1007/s11142-012-9194-7

Publisher: Springer Science + Business Media B.V.

Persistent URL: http://hdl.handle.net/1721.1/75117

Version: Author's final manuscript: final author's manuscript post peer review, without publisher's formatting or copy editing

Terms of use: Creative Commons Attribution-Noncommercial-Share Alike 3.0 


\title{
Where Do Firms Manage Earnings?
}

\author{
Scott Dyreng \\ Duke University \\ Michelle Hanlon \\ MIT \\ Edward L. Maydew \\ University of North Carolina
}

First Draft: September 2010

This Draft: May 2011

\begin{abstract}
Despite decades of research on how, why, and when companies manage earnings, there is a paucity of evidence about the geographic location of earnings management within multinational firms. In this study, we examine where companies manage earnings using a sample of 2,067 U.S. multinational firms from 1994-2009. We predict and find that firms with extensive foreign operations in weak rule of law countries have more foreign earnings management than companies with subsidiaries in locations where the rule of law is strong. We also find some evidence that profitable firms with extensive tax haven subsidiaries manage earnings more than other firms, and that the earnings management is concentrated in foreign income. Apart from these results, we find that most earnings management takes place in domestic income, not foreign income.
\end{abstract}

We appreciate helpful comments from Dirk Black, Jürgen Ernstberger, Jeff Hoopes, Alina Lerman, Terry Shevlin, Nemit Shroff, Shyam Sunder, Jake Thomas, Jake Thornock, Frank Zhang, and workshop participants at the 2011 European Accounting Association Annual Congress, Florida State University, University of Chicago, University of Notre Dame, University of Southern California, Texas A\&M University, and the Yale 2010 Accounting Research Conference. Maydew acknowledges financial support from The Arthur Andersen Faculty Fund. 


\section{Where Do Firms Manage Earnings?}

\section{Introduction}

The study of earnings management dates back to at least Healy (1985). ${ }^{1}$ In the subsequent decades, researchers have conducted hundreds of studies of earnings management. Among other things, these studies have provided insights into when firms manage earnings, what types of accounts they manage, why they manage earnings, and how they manage earnings. ${ }^{2}$ Surprisingly, however, there is a paucity of evidence about where firms manage earnings. Does earnings management generally take place in a firm's foreign operations, far from headquarters and perhaps the scrutiny of auditors, or does it take place closer to home? This study provides initial evidence on the location of earnings management.

Prior research has examined whether the location of a firm's headquarters or location of incorporation is associated with measures of earnings management (e.g., Leuz et al. (2003)). In such studies, the broad research question is whether the institutions, customs, laws, and accounting standards in the firm's parent location affect financial reporting. In our study, we take the next step to investigate this broad question, but we go inside the firm to examine whether the institutions and laws, including tax laws, in the locations of the firm’s subsidiaries (proxied by the World Bank 'rule of law' and tax haven status (including bank secrecy)) are associated with differences in earnings management in reported financial statements of the entire, consolidated company. Thus, the question is whether the institutional features of the subsidiaries affect financial reporting (via allowing or mitigating earnings management), despite the firm as a whole

\footnotetext{
${ }^{1}$ Indeed, research on the related phenomenon of accounting method choice dates back to studies such as Watts and Zimmerman (1978), Hagerman and Zmijewski (1979), Bowen, Noreen, and Lacey (1981), and Holthausen (1981).

${ }^{2}$ For reviews see Healy and Whalen (1999), Schipper (1999), Dechow and Skinner (2000), Fields, Lys and Vincent (2001), and Dechow, Ge and Schrand (2010).
} 
being subject to U.S. Generally Accepted Accounting Principles (GAAP) and Securities and Exchange Commission (SEC) regulations.

We examine a sample of U.S.-based multinational firms from the years 1994 to 2009, constituting 11,077 firm-years. Our study focuses on multinational firms; therefore, we exclude purely domestic firms to avoid the trivial result that domestic firms by definition manage only domestic earnings. An important aspect of our sample is that GAAP and the regulatory environment is presumptively held constant at the firm level, in the sense that a U.S. listed firm is subject to U.S. GAAP and U.S. securities laws across its entire operations, whether domestic or foreign. Our first set of tests examines whether companies with a higher concentration of material subsidiaries (disclosed in exhibit 21 of the 10-K) in low rule of law locations or tax haven locations have more discretionary accruals. Our second set of tests is aimed at identifying whether earnings management occurs in foreign earnings or in domestic earnings by examining the mapping of foreign and domestic earnings into discretionary accruals. We also test the frequency of earnings restatements across the partitions of firms as an alternative measure of earnings management.

We report three main findings. First, the data show that overall earnings are managed less when the firm has a high concentration of subsidiaries in foreign countries with a strong rule of law. This differential in earnings management for firms with subsidiaries in high rule of law countries is more pronounced in foreign income, consistent with the earnings management occurring in the foreign jurisdiction. Again, we are not comparing earnings management of foreign firms to U.S. firms - all the firms in the sample are U.S. domiciled firms and thus subject to U.S. laws and accounting standards. Thus, despite the firm being subject to U.S. GAAP and 
SEC rules, the data are consistent with the geographic location of a U.S. firm’s foreign subsidiaries being associated with significant differences in earnings management.

Second, we find that profitable firms with extensive tax haven subsidiaries engage in more earnings management, which is also concentrated in foreign earnings. This is not simply a manifestation of tax havens reducing the tax expense - we measure earnings management before taxes. Rather, we posit that tax havens are more desirable locations for earnings management because there is no local tax cost as a result of managing pre-tax income (and likely no U.S. tax cost because cash repatriations are not affected). For example, Erickson et al. (2004) find that firms engaging in fraudulent accounting incur actual tax costs when inflating their accounting earnings. They conjecture that firms can minimize the tax cost of such activities to the extent they can do so in a tax haven. In addition, Desai and Dharmapala (2006) observe that the same types of activities and structures that facilitate tax avoidance via tax havens can be used to facilitate managerial misappropriation. Our predictions are based on implications from these prior papers - earnings management can generate tax costs that can be avoided in tax havens, and the structures employed in tax haven subsidiaries provide obfuscation that aids earnings management activities.

Finally, apart from the above results, earnings management appears to be more prevalent in domestic income than in foreign income. This is not a simple result of domestic operations being larger in scale than foreign operations; on average, foreign and domestic operations are of the same order of magnitude for the firms in our sample.

We conduct a number of additional tests to examine the robustness of the results, including examining the absolute value of discretionary accruals, controlling for performance differences across firms, using different measures of rule of law and tax haven status, and using 
restatements as the indication of earnings management instead of discretionary accruals. Across these tests the main results are generally consistent and in line with the above findings. One exception is that when examining restatements we do not find evidence that firms operating in tax havens are more likely to restate their financial statements. The evidence on rule of law continues to hold in the restatement sample as it did in the discretionary accruals tests.

We contribute to the literature by examining a new aspect of earnings management - the role of the geographic footprint of a U.S. multinational's subsidiaries. Specifically, we show that the previously documented effect that rule of law has on earnings management is actually much more pervasive. Not only does the rule of law in the parent company's jurisdiction matter, but so does the rule of law in the jurisdictions of the firm's subsidiaries. In addition, we show that subsidiary structures involving tax havens are associated with higher discretionary accruals for profitable firms. Finally, policymakers will find the results of this study interesting, particularly to the extent they have expressed concern about auditing and accounting in the foreign operations of U.S. multinationals and as they consider U.S. policies toward tax haven nations.

The paper proceeds as follows. In the next section, we review the prior literature with particular attention to research that provides a basis for our predictions about the geographical incidence of earnings management. In section 3, we develop our hypotheses. In section 4, we discuss our sample, variable measurement, and empirical tests. Section 5 presents our results, and section 6 concludes.

\section{Background and Prior Literature}

\subsection{The Regulation of Multinational Companies}

Our inquiry focuses on U.S. multinationals and the management of earnings within the firm, i.e., where do multinationals manage earnings. Because our sample consists entirely of U.S. 
SEC registrants, all the companies are required to apply U.S. GAAP to their financial statements regardless of where the underlying operations are located. ${ }^{3}$ In our sample, the top-level regulatory environment is held constant across our firms. What varies, however, are the local legal and regulatory environments of the countries in which foreign subsidiaries are located.

The ability of the U.S. to effectively exert regulatory control over the accounting in the foreign operations of U.S. multinationals has been a longstanding issue. For example, the Foreign Corrupt Practices Act (FCPA) of 1977 aims to prevent U.S. companies and their agents from bribing foreign officials. The FCPA also contains important accounting provisions that require U.S. registrants to maintain a system of internal controls that provide reasonable assurance that, among other things, the transactions are properly recorded to permit preparation of financial statements in conformity with GAAP (Golden et al., 2006).

The PCAOB has also expressed concern with quality control in audits across borders. The then-acting chairman, Daniel L. Goelzer, in a recent speech stated the following concerns: 1) U.S. engagement partners sometimes do not have a sufficient basis on which to assess whether the non-U.S. audit personnel are qualified and familiar with U.S. GAAP, PCAOB standards, and SEC requirements, 2) internal inspection information about foreign-affiliate firms and personnel are sometimes not made available to the audit engagement partners and at times, engagement partners fail to even ask for it, 3) audit firms may not have minimum levels of training for GAAP, PCAOB standards, or SEC requirements for foreign-affiliate personnel, and 4) U.S. engagement teams sometimes fail to appropriately evaluate the results of a foreign affiliate's

\footnotetext{
${ }^{3}$ The subsidiary may also be required to prepare financial statements in accordance with local GAAP for a variety of reasons. Our point here is that when the earnings are consolidated and reported for the entire company, all the earnings are reported using GAAP and are subject to U.S. securities laws.
} 
work, or fail to adequately supervise and control the affiliate’s work. ${ }^{4}$ Thus, while subsidiaries need to report their earnings following U.S. GAAP, the local institutions will vary at the locations of the subsidiaries and the knowledge of U.S. GAAP and securities laws may vary across personnel at the companies and at the audit firms.

To provide some examples of earnings management in foreign subsidiaries we look to cases of extreme earnings management resulting in fraud, which are detailed in SEC Accounting and Auditing Enforcement Releases (AAERs). For example, the SEC in AAER No. 2727 accuses Bristow Group Inc. (a Delaware corporation with headquarters in Houston, Texas) of improprieties at a foreign subsidiary. Specifically, Bristow’s wholly owned U.S. subsidiary, AirLog International, Ltd., through its Nigerian affiliate, Pan African Airlines Nigeria Ltd. (PAAN) made improper payments (bribes) totaling approximately $\$ 423,000$ to employees of the governments of two Nigerian states. These improper payments, however, were not properly recorded in AirLog's books and were never included in Bristow’s consolidated statements. Bristow’s internal controls failed to detect and prevent the improper payments. In another example, the SEC concluded that a Japanese subsidiary of Boston Scientific recorded false sales and materially overstated its earnings for several years in the 1990s, which then caused material misstatements in Boston Scientifics’ consolidated financial statements (AAER 1295).

In sum, there is concern by accounting regulators about foreign operations of U.S. multinationals, and there exist examples of extreme earnings management in foreign operations. However, there are also specific examples of earnings management involving domestic operations. What is lacking is large sample evidence about the geographic location of earnings management within firms and the factors that drive the location. There is, however, prior

\footnotetext{
${ }^{4}$ December 7, 2009 speech before the AICPA National Conference on Current SEC and PCAOB Developments, Washington, DC.
} 
research that informs our thinking of how the geographic incidence of earnings management within the firm might play out, and we turn to this research in the next section.

\subsection{Prior Literature}

There is little prior research on where, within a multinational company, earnings are managed. Leuz et al. (2003), in an influential paper, examine earnings management around the world in a sample of over 8,000 firms from 31 countries and provide evidence of the importance of institutional features on accounting. For example, they provide evidence that earnings management is more likely to occur at companies that are located in countries where investor protection is weaker, reasoning that such protection prevents the extraction of private benefits by insiders and thus reduces the incentives to obfuscate information. However, Leuz et al. (2003) does not examine earnings management within the firm. In other words, Leuz et al. compare a U.S. domiciled company to a firm domiciled in Singapore, for example, but they do not compare the domestic earnings of a U.S. multinational to the foreign earnings of that same multinational company.

Kedia and Rajgopal (2011) examine the geography of financial misreporting but their study is focused on the location of corporate headquarters relative to an SEC office. If corporate headquarters is in a county far from an SEC office and the local auditor office in the county is lax, companies in that county report a higher incidence of earnings decreasing restatements. Dyreng et al. (2010), Grullon et al. (2010), and McGuire et al. (2010) examine the effect of social norms on earnings management. These studies generally find that firms located in counties with high levels of religious adherence are less likely to engage in earnings management. While related and interesting, these papers examine differences in earnings management across firms and do not look at the location of the earnings management within the firm. 
Other papers do examine the foreign earnings relative to the U.S. earnings of U.S. multinational corporations, but these papers do not examine the extent of manipulation of those earnings. More importantly, the studies do not investigate the effect of the institutional features of the location of the earnings on earnings properties. These papers are primarily concerned with the relative market valuation of the earnings. For example, Bodnar and Weintrop (1997) examine the relation between returns and domestic and foreign incomes and report that foreign earnings having a greater association with returns, consistent with the foreign earnings being related to growth opportunities reflected in returns. While these authors examine currency exchange rates and the timeliness of information related to foreign versus domestic operations, there is no investigation of differential earnings management in the foreign versus domestic earnings and no examination of cross-sectional variation in the foreign locations and the resulting effect on reported earnings.

Another example is Thomas (1999), who examines whether abnormal returns can be earned using information about firms’ foreign versus domestic earnings. In a Mishkin (1983) framework, Thomas examines whether foreign earnings have different persistence than domestic earnings and whether trading profits can be earned via trading on the knowledge of such a difference. Thomas reports that foreign earnings have greater persistence than domestic earnings but that the market underestimates the persistence of foreign earnings, leading to predictable future returns. Hope et al. (2008) extend Thomas (1999) and report evidence consistent with investor mispricing of foreign earnings decreasing after the adoption of SFAS 131 Disclosures about Segments on Enterprise and Related Information. While these papers consider foreign versus domestic earnings, their focus is on mispricing, not where multinationals undertake earnings management. 
Perhaps most closely related to our paper are two working papers: Durnev, et al. (2009) and Beuselinck et al. (2010). Durnev et al. (2009) examine governance at offshore financial centers and the effects on earnings management. The authors group together companies incorporated in an offshore financial center and U.S. domiciled firms that have affiliates in offshore financial centers as "offshore firms," to which they compare other U.S. firms without offshore affiliates. The authors report evidence consistent with offshore firms engaging in more earnings management than non-offshore firms. Further, they document that companies with a higher Offshore Attitude Index, intended to measure the firm's institutional and legal environment, manage earnings more with accruals than with real earnings management. Finally, the authors predict and find that earnings management of firms listed or cross-listed in the U.S. will be different from pure offshore firms and examine whether the Sarbanes-Oxley Act significantly decreased accruals management of the listed and cross-listed firms. The authors find evidence consistent with their conjectures.

The other concurrent working paper, Beuselinck et al. (2010), examines earnings management in European subsidiaries of EU-based multinational corporations. The authors find that earnings management is higher at the subsidiary level when the subsidiary-country institutional quality is weak. They also document evidence consistent with the MNC parent governance characteristics affecting the magnitude of subsidiary earnings management over and above subsidiary-specific characteristics. The authors conclude that the parent level characteristics have contagion effects for their subsidiary-level financial reporting quality.

A final related working paper is Fan (2008), who examines whether earnings management is evident in foreign earnings of U.S. multinationals and whether the earnings management pattern changed after the adoption of SFAS 131. Fan uses the Burgstahler and 
Dichev (1997) discontinuity in the distribution of earnings levels and earnings changes as the measure of earnings management. Fan reports evidence consistent with foreign earnings being managed to avoid a loss but not to avoid an earnings decrease. She also reports that domestic earnings are not managed to avoid a loss. She does not find a significant difference, on average, between the pre-and post-FAS 131 periods in loss avoidance behavior.

In sum, there are a few related studies that have addressed aspects of our research question. However, the evidence, even when pieced together, is inconclusive. For example, Thomas (2000) documents that foreign earnings are more persistent than domestic earnings, while Fan (2008) documents that foreign earnings are used more often than domestic earnings to avoid a loss for U.S. multinationals. Neither of these studies examines the institutional forces at work at the various locations (e.g., in a tax haven or not, or in a location with a strong rule of law or not). In contrast, Leuz et al. (2003) focuses a great deal on the institutional forces but does not study earnings management within a multinational firm. Rather, Leuz et al. (2003) was an early and important study on the earnings quality of firms located in different countries operating under different standards, legal environments, and governance/shareholder protection regimes. Durnev et al. (2009) is closer to our study but focuses exclusively on offshore financial centers, combining multinational firms with affiliates in these centers with firms domiciled in these centers. Despite the advances made in understanding earnings management, it is not known whether U.S. multinational firms have more earnings management in domestic earnings, foreign earnings, or both, and whether such earnings management is affected by the local institutional regimes in which its foreign subsidiaries operate. ${ }^{5}$

\footnotetext{
${ }^{5}$ Other tangentially related papers include Duru and Reeb (2002), who report evidence that analysts have lower forecast accuracy when firms have greater international diversification, and DeFond et al. (2007), who provide evidence that earnings announcements are more informative in countries with strong investor protections.
} 


\section{Hypothesis Development}

Earnings management can occur at the direction of central management or via the conduct of a division or subsidiary manager. ${ }^{6}$ In our setting, the predictions are the same in either case. For example, if central managers decide to engage in earnings management, they must decide whether to manage via domestic income, foreign income, or both. Managers are expected to consider the expected costs of earnings management, including the likelihood of being challenged or discovered. In addition, managers will consider the potential benefits of earnings management such as higher compensation (Healy, 1985) or avoiding the violation of a debt covenant (DeFond and Jiambalvo, 1994; Sweeney, 1994; and Dichev and Skinner, 2002), for example. The expected likelihood of being caught may be lower for domestic earnings management, if directing earnings management in the foreign jurisdiction would involve more people or would involve people that do not have a close working relationship with top management. In other words, to the extent that top management wants to limit the number of people involved and keep the misreporting close to the parent company, earnings management will occur in domestic income. However, it is possible that foreign income will be managed more in order to avoid getting caught. For example, if the Kedia and Rajgopal (2011) result (that firms further from the SEC offices manage earnings more than firms close to SEC offices) can be generalized to U.S. subsidiaries relative to foreign subsidiaries, then more earnings management will take place in foreign jurisdictions. Because there are reasons for earnings management to be

\footnotetext{
${ }^{6}$ In an analysis of fraudulent financial reporting over the period 1998 to 2007, the Committee of Sponsoring Organizations of the Treadway Commission (COSO) states, "The SEC named the CEO and/or CFO for some level of involvement in 89 percent of the fraud cases, up from 83 percent of cases in 1987-1997. Within two years of the completion of the SEC's investigation, about 20 percent of CEOs/CFOs had been indicted and over 60 percent of those indicted were convicted" (COSO, 2010). Thus, many cases of financial manipulation name central managers as the guilty party. However, some cases are done by "rogue" managers, as the two SEC AAER cases in section 2 indicate. Top management at Boston Scientific and Bristow did not appear to be, and were not accused of being, involved in the fraud.
} 
located either more or less in foreign earnings than domestic earnings, we make no directional prediction with regards to the overall geographic location of earnings management.

Our first directional prediction (Hypothesis 1) focuses on the rule of law in the foreign countries where the firm's subsidiaries are located. We predict that the local legal systems of the firm's subsidiaries affect the firm's propensity to engage in earnings management, such that having subsidiaries in weak rule of law countries will be associated with more earnings management. The effect of local institutions on accounting quality has been shown in prior literature, as discussed above (e.g., Leuz et al. (2003)). It is possible that earnings management in foreign operations is less likely to be challenged, and if so, the consequences are likely to be less stringent when there is a weak rule of law. Audits of foreign operations are typically performed by foreign affiliates of the auditor or, in some cases, by an unrelated foreign audit firm. If those audits are lacking the same rigor as the audit of the U.S. operations, as suggested is often the case by the PCAOB Chair as discussed above, then the managers might face less chance of being challenged if they manage foreign income, particularly so if the rigor of the local audit is affected by the local rule of law. The effect of local rule of law on earnings management, if any, is interesting when examining the earnings of subsidiaries of U.S. multinationals because the earnings of subsidiaries are required to be reported under U.S. GAAP and U.S. securities laws. The U.S. is considered to have a strong rule of law, which ideally should act as a constraint on earnings management in both domestic and foreign operations, in which case weaker constraints based on local law would not matter.

Our second directional prediction (Hypothesis 2) focuses on the role of tax havens in earnings management. We predict that having subsidiaries in tax havens is associated with more earnings management. This prediction comes in part from Erickson et al. (2004), which 
examines whether firms engaging in accounting fraud pay taxes on the fraudulent earnings. Erickson et al. (2004: 391) do not study where firms managed the earnings or whether the taxes were foreign or domestic, but the authors conjecture that "the firm might overstate the income of a foreign subsidiary located in a low-tax country.” Managing earnings in a tax haven avoids cash tax payments and as well as the accounting income tax expense in most cases (see Erickson et al. (2004) for details). Another reason why we expect to see more earnings management for firms with tax haven subsidiaries comes from Desai, Dyck and Zingales (2007) and Desai and Dharmapala (2006). Those studies posit that the same structures and activities conducive to tax avoidance (i.e., complex structures and secrecy) are also conducive to private diversion of the firm's resources by managers. Indeed, the authors argue that the primary intent of many tax shelters is to increase accounting earnings. Furthermore, in a report by the Joint Committee of Taxation (JCT) prepared for the Senate Finance Committee, the JCT noted that Enron created many entities in jurisdictions that did not impose a tax on such entities (e.g., tax havens). In particular, as of December 31, 2001, the Enron ownership structure included 441 entities formed in the Cayman Islands, a country that has never imposed a corporate income tax. These entities were used to route transactions, through which the company was able to increase earnings (e.g., LJM Cayman) without incurring additional taxes.

Of note is that our hypothesized prediction for tax havens is most applicable to profitable, tax-paying firms. Our prediction is that tax havens allow earnings management in a tax free manner, which implies that taxes are costly for the firm. As a result, in the tests that follow we estimate our regressions over the full sample and separately over a subsample of profitable firms (i.e., positive pre-tax domestic and foreign earnings). 
In addition, it is important to note that our prediction about earnings management in tax havens relates to management of pre-tax accounting income. The income and accruals measures that we examine are pre-tax and thus are not affected by reductions in tax expense. Also, the earnings management that we observe in our measures is not simply a manifestation of transfer pricing for tax purposes. Such tax-motivated income management involving tax havens typically involves shifting income across jurisdictions (e.g., U.S. to foreign) within the current year. While this can increase pre-tax foreign income and decrease pre-tax domestic income, it will not affect total consolidated pre-tax earnings. In contrast, accounting-motivated earnings management (i.e., management that would affect total earnings reported on the company's annual SEC filing), involves shifting income over time (e.g., accruals that increase current year income and decrease next year's income or real transactions accelerated into the current period).

\section{Variables, Sample, and Descriptive Statistics}

\subsection{Variables}

We examine two measures of discretionary accruals in our analyses, and later in the paper we examine restatements as well. The first is signed pre-tax discretionary accruals, PTDACC. The second is the absolute value of pre-tax discretionary accruals (|PTDACC|). The absolute value of discretionary accruals is useful as a dependent variable to capture both incomeincreasing and income-decreasing earnings management when there is reason to expect both types of earnings management in a sample. ${ }^{7}$

Note that data on foreign operations is extremely limited from public sources, especially following the implementation of SFAS 131, and thus direct tests of earnings management in

\footnotetext{
${ }^{7}$ Studies examining the absolute value of discretionary accruals include Dechow and Dichev (2002), Frankel, Johnson, and Nelson (2002), Klein (2002), Chung and Kallapur (2003), Myers, Myers, and Omer (2003), Leuz, Nanda, and Wysocki (2003), and Bergstresser and Philippon (2006). As discussed later, we control for operating volatility in our analyses, following the recommendations of Hribar and Nichols (2007).
} 
specific foreign locations are difficult. We employ company-wide measures of discretionary accruals and conduct an array of cross-sectional tests using the rule of law and tax haven location in order to investigate our research question.

We measure discretionary accruals according to the modified Jones model, before taxes (Dechow et al., 1995). We expect tax haven usage to facilitate the management of pre-tax accounting income, because the earnings management will be tax-free. Thus, we exclude discretionary accruals that may arise from managing tax expense. Specifically, we start with pretax accruals, PTACC, defined as pre-tax income $(P I)$, less pre-tax cash flow, which is cash flow from operations ( $C F O)$, plus cash tax paid, less cash from extraordinary items and discontinued operations, all measured for the current year and scaled by total assets: ${ }^{8}$

$$
P T A C C_{i t}=P I_{i t}-\left(C F O_{i t}+T X P D_{i t}-X I D O C_{i t}\right) .
$$

Then, PTDACC (pre-tax discretionary accruals) is the estimated residual $\left(\hat{\epsilon}_{i t}\right)$ from the following model (estimated by 2-digit SIC and year):

$$
\operatorname{PTACC}_{i t}=\alpha_{0}+\alpha_{1} \frac{1}{A_{i t-1}}+\alpha_{2} \frac{\left(\Delta S A L E S_{i t}-\Delta A R_{i t}\right)}{A_{i t-1}}+\alpha_{3} \frac{\left(P P E_{i t}\right)}{A_{i t-1}}+\epsilon_{i t},
$$

where $\triangle S A L E S$ is the change in sales from the prior year to the current year, $\triangle A R$ is the change in accounts receivable from the prior year to the current year, and $P P E$ is gross property, plant and equipment at the end of the year.

The explanatory variables of most interest are RULE OF LAW and HAVEN INTENSITY. RULE OF LAW is measured as the average rule of law of countries in which the firm discloses subsidiaries in Exhibit 21 of Form 10-K.The rule of law scores for each country are from the World Bank Governance Indicators dataset. RULE OF LAW will be high when the firm's

\footnotetext{
${ }^{8}$ Firm, time, and industry subscripts are omitted for expositional ease.
} 
material subsidiaries are predominantly located in countries with a strong rule of law. RULE OF $L A W$ captures perceptions of the extent to which agents have confidence in and abide by the rules of society, and in particular the quality of contract enforcement, property rights, the police, and the courts, as well as the likelihood of crime and violence. ${ }^{9}$ We predict that despite our sample firms being subject to U.S. GAAP and U.S. securities laws on their worldwide earnings, the local legal systems of their subsidiaries will affect their propensity to manage earnings, such that more earnings management takes place when the subsidiaries are located in countries with weak rule of law.

HAVEN INTENSITY is measured as the number of subsidiaries located in tax haven countries, divided by the total number of subsidiaries. Data on subsidiaries are from Exhibit 21 of the Form 10-K, where firms are required to list their subsidiaries with material operations. Tax havens are identified as countries that are on at least two of the four commonly used tax haven lists. ${ }^{10}$ While there is not an official definition of a tax haven, the Organization for Economic Cooperation and Development (OECD) lists criteria to being labeled a tax haven including 1) imposing no or only nominal taxes, 2) a lack of transparency, 3) laws or administrative practices that prevent the effective exchange of information for tax purposes with other governments on taxpayers benefiting from the no or nominal taxation, and 4) an absence of a requirement that the activity be substantial. ${ }^{11}$ We expect a positive relation between HAVEN INTENSITY and the magnitude of discretionary accruals.

We include variables to control for the general complexity of the firm, the scope of its foreign operations, and the macroeconomic conditions of the countries in which it has

\footnotetext{
${ }^{9}$ See http://info.worldbank.org/governance/wgi/pdf/rl.pdf for a detailed discussion and listing of factors.

${ }^{10}$ We use the lists in Miedema (2008) as per Dyreng and Lindsey (2009).

${ }^{11}$ See http://www.oecd.org/document/23/0,3343,en_2649_33745_30575447_1_1_1_1,00.html for further details.
} 
subsidiaries. We measure the extent to which the firm has special purpose entities, SPE INTENSITY, as the number of LLC, LP, and Trusts divided by the total number of subsidiaries on Exhibit 21. Prior research has used this approach to identify special purpose entities and shown that their use is associated with an increased propensity to disclose material weaknesses (Doyle, Ge, and McVay, 2007). ${ }^{12}$ We include two measures of the scope of foreign operations. The first, FOREIGNNESS, is foreign sales divided by total sales of the entire company. The second is the natural log of the number of countries in which the company has material subsidiaries, NCOUNTRIES. We include a measure of firm size, defined as the natural log of the firm's assets, SIZE. We also include variables that reflect time-varying macroeconomic characteristics of the countries in which the firm operates. The first, CPI CHANGE SUB COUNTRIES, reflects the weighted average of the change in the consumer price index of the countries in which the firm operates. The second, GDP CHANGE SUB COUNTRIES, reflects the weighted average of the change in gross domestic product of the countries in which the firm operates. These two variables are gathered from the World Economic Outlook Database, April 2010 edition, available from the International Monetary Fund.

Finally, we include two variables to reflect the operating volatility of the firm. Hribar and Nichols (2007) suggest including these variables when using the absolute value of discretionary accruals as a dependent variable. We include the variables in our signed accruals tests as well for ease of comparability. SALES VOLATILITY is the rolling 5-year standard deviation of sales, from year $\mathrm{t}$ to $\mathrm{t}-4$. CASH FLOW VOLATILITY is the rolling 5-year standard deviation of cash flow from operations (from the statement of cash flows), going from $t$ to $t-4$.

\footnotetext{
${ }^{12}$ This definition captures noncorporate entities, which may not all meet the technical definition of an SPE. We follow prior convention for labeling purposes but recognize that there is measurement error in this variable.
} 


\subsection{Sample and Descriptive Statistics}

Our sample selection criteria are described in Table 1. We begin with all U.S. incorporated firm-years listed on Compustat during the period 1994-2008, excluding only the smallest of firms (assets less than $\$ 1$ million or lagged assets less than $\$ 1$ million), firms in regulated industries, and those with missing values for pre-tax income, operating cash flow, cash taxes, change in sales, change in receivables, and gross property, plant and equipment. This gives us an initial sample of 78,448 firm-years. From these observations, we exclude firm-years that belong to industry-years with less than 10 observations. We calculate our modified measure of Jones model discretionary accruals using this slightly reduced sample of 69,819 firm-years. To investigate the incidence of earnings management in domestic and foreign income, we need companies to have foreign income. When we require firm-years to have non-missing values for pre-tax domestic and foreign income, we obtain 32,734 firm-years. Finally, we require nonmissing data to compute the independent variables in the study. Many of these variables, which are described below, are based on data from Exhibit 21 of the 10-K, where firms are required to list their material subsidiaries. As stated above, we use these data to compute measures of tax haven intensity, rule of law, and special purpose entity intensity. After applying these screens, the main sample used in our tests has 11,077 firm-years from 2,067 firms.

Table 2 presents the breakdown of the sample across the Fama-French 30 industries. ${ }^{13}$ The sample is well spread over industries, with no industry accounting for more than 22 percent of the firms. Most industries account for 1 to 5 percent of the firms. Relative to the Compustat population, our sample appears to over-represent some industries and under-represent others. The biggest deviation is in the Business Equipment industry, which accounts for 21 percent of

\footnotetext{
13 The financials and utilities industries are dropped because we eliminate regulated industries from the sample. Of the 14 firms in Compustat in the tobacco industry, none fulfill all of our sample criteria. Thus, we include a breakdown of 27 (not 30) industries in Table 2.
} 
our sample, but only 13 percent of the Compustat sample. Other deviations are smaller.

Descriptive statistics for the main variables in the study are presented in Table 3. Pre-tax discretionary accruals have a mean (median) of $0.003(0.011)$ in the sample. ${ }^{14}$ The absolute value of pre-tax discretionary accruals has a mean (median) of $0.064(0.041)$. This is smaller than the 0.101 mean absolute value of discretionary accruals in Hribar and Nichols (2007), but this is to be expected since our sample includes only multinational firms and Hribar and Nichols (2007) show that larger firms have smaller absolute value of discretionary accruals. As the sample consists of multinationals, foreign operations are a substantial part of the firms in the sample. The mean pre-tax domestic income is 0.026 in the sample, which is slightly smaller than the mean pre-tax foreign income of 0.028 . The median firm still has more domestic income, however, with median pre-tax domestic income of 0.036 compared to median foreign pre-tax income of 0.019 .

RULE OF LAW has a mean (median) value of 1.065 (1.087). The raw Rule of Law measure from the World Bank is designed so that it is mean zero, with a standard deviation of one across all countries in a given year. Thus, the firms in the sample tend to have most of their subsidiaries in high rule of law countries. There is a substantial use of tax haven subsidiaries in the sample, consistent with widespread use of tax haven subsidiaries among multinational firms in general. The variable HAVEN INTENSTIY has a mean (median) of 0.177 (0.146), indicating that 17.7 percent of the average firm’s material foreign subsidiaries are located in tax havens. Most firms in the sample do not report special purpose entities (at least among their material subsidiaries), with a median SPE INTENSITY of zero in the sample, and a mean of 0.058 . The mean (median) value of 0.381 (0.358) for FOREIGNNESS (foreign sales from Compustat

\footnotetext{
${ }^{14}$ The mean is not zero because the model is estimated over the larger 69,819 firm-year sample, which is prior to imposing other data requirements to arrive at the final sample.
} 
geographic segment data divided by total sales from Compustat) indicates that a large percentage of sales of the firms in the sample are earned in foreign jurisdictions. CASH FLOW VOLATILITY and SALES VOLATILITY have mean values of 0.062 and 0.232, respectively. NCOUNTRIES has a mean (median) value of 2.348 (2.398), and since it is the natural log of the number of countries in which the firm reports material subsidiaries, indicates that the mean firm has material subsidiaries in approximately 10 countries. The natural log of the firms' assets, SIZE, has a mean (median) value of 6.716 (6.676). The variable CPI CHANGE SUB COUNTRIES, the measure of the average rate of inflation in countries in which the sample firms have subsidiaries, has a mean (median) of 5.205 (3.003). The variable GDP CHANGE SUB COUNTRIES, a measure of the average change in gross domestic product in the countries in which the sample firms have subsidiaries, has a mean (median) of 3.444 (3.494).

Table 4 reports the correlations among these variables. The Pearson correlations are in the upper right and the Spearman correlations are in the lower left. Consistent with Hribar and Nichols (2007) we find positive correlations between the absolute value of (in our case pre-tax) discretionary accruals and the volatility of cash flows and sales and a negative correlation with firm size. The number of countries in which the firm lists material subsidiaries is also negatively correlated with the absolute value of pre-tax discretionary accruals. We next turn to the multivariate tests.

\section{Empirical Tests and Results}

\subsection{Foreign Subsidiaries and Discretionary Accruals}

Our first set of analyses examine whether foreign subsidiary characteristics are associated with discretionary accruals. Three models with different combinations of explanatory variables are estimated, with the full model as follows: 


$$
\begin{aligned}
\text { PTDACC }_{i t}= & \alpha_{0}+\alpha_{1} \text { RULE OF LAW }_{i t}+\alpha_{2} \text { HAVEN INTENSITY }_{i t} \\
& +\sum \alpha_{k} \text { CONTROL }_{i t}^{k}+\epsilon_{i t} .
\end{aligned}
$$

The results are presented in Table 5, Panel A. ${ }^{15}$ In the first column, we present the results with RULE OF LAW and control variables, but excluding HAVEN INTENSITY. In the second model, we present results with HAVEN INTENSITY, but not RULE OF LAW. The full model with all of the explanatory variables is presented in the rightmost column labeled "Model 3." RULE OF LAW is negative and significant in both specifications where it appears (-0.687 in Model 1; -0.688 in Model 3). This is consistent with the prediction that firms with subsidiaries located in strong rule of law countries manage their earnings less than firms with subsidiaries located in weak rule of law countries. HAVEN INTENSITY is not significantly different from zero in Model 2 or in Model 3. A positive coefficient would be consistent with the prediction that firms with more subsidiaries located in tax havens have more earnings management, as proxied by discretionary accruals.

The analysis in Panel A includes all observations regardless of whether they are profitable firms or loss firms. However, there is evidence that discretionary accruals can be asymmetric with respect to losses (Ball and Shivakumar, 2006). Moreover, as stated above, our hypothesis about earnings management being concentrated in tax havens presumes that firms are profitable, tax-paying firms. Loss firms are unlikely to face significant tax costs from earnings management in the first place, and thus are less likely to focus their earnings management in tax havens. Accordingly, in Panel B of Table 5 we re-estimate equation (3) over the set of firm-years

\footnotetext{
${ }^{15}$ We utilize robust regression to control for outliers. In the regressions, all continuous variables are mean centered at zero for ease of interpretation of the interaction effects (Aiken and West, 1991). We multiply the dependent variable by 100 to facilitate interpretation of the coefficients as percentages. The standard errors in all regressions are computed after clustering observations by firm and year to mitigate the effects of cross-sectional and intra-firm correlation in the residuals (Petersen, 2009). For all regressions we present one-tailed p-values for t-statistics where we have a prediction and two-tailed p-values otherwise.
} 
that have positive pre-tax foreign and positive pre-tax domestic income. The results in Panel B indicate that among profitable firms, earnings management is increasing in the extent to which the firms have tax haven subsidiaries. The coefficient on HAVEN INTENSITY is positive and significant in both specifications where it is included, ranging from 0.828 in column (2) to 0.836 in column (3). As in the broad sample of firms, RULE OF LAW is negative and significant, as predicted, in each specification where it is included.

In terms of the control variables, the results in Table 5 show a consistently positive coefficient on FOREIGNNESS and a consistently negative coefficient on SIZE. Coefficients on CASH FLOW VOLATILITY are significantly negative across all specifications. These findings are consistent with the modified Jones model better explaining accruals, and thus leaving less to be labeled discretionary, for large firms and firms with low operating volatility (Hribar and Nichols, 2007). We also find consistently negative coefficients on CPI CHANGE SUB COUNTRIES and GDP CHANGE SUB COUNTRIES. We have no directional prediction for these variables, but include them to control for macroeconomic conditions in the countries in which the firm operates.

To graphically illustrate the effect of RULE OF LAW and HAVEN INTENSITY on PTDACC, we replace the continuous variables RULE OF LAW and HAVEN INTENSITY in Panel B of Table 5 with indicator variables that capture quintiles of RULE OF LAW and HAVEN INTENSITY. The coefficient values for each of the quintiles are then plotted in Figure 1. As the figure shows, the effect of RULE OF LAW on PTDACC is greatest when moving from the first to second quintile, and then continues to strengthen through the fifth quintile. The effect of HAVEN INTENSITY on PTDACC appears to be greatest when moving from the second to third quintile of 
HAVEN INTENSITY, and again from the fourth to fifth quintiles, with the largest effect concentrated in the quintile containing the most haven intense firms.

\subsection{Discretionary Accruals on Foreign and Domestic Pre-tax Income}

In Table 6 we examine the mapping of foreign and domestic pre-tax income into discretionary accruals. The idea is to examine how earnings management can be attributed to domestic versus foreign activity by directly including measures of such activity. Since U.S. firms are required to disclose the breakdown of their pre-tax income into pre-tax domestic and pre-tax foreign income, those data are available for a broad sample. ${ }^{16}$ First, we define the rate of company-wide discretionary accruals as:

$$
\text { PTDACC RATE } E_{i t}=\frac{P T D A C C_{i t}}{P I_{i t}} .
$$

This ratio captures the fraction of total pre-tax income that is estimated to be discretionary accrual income. Re-arranging the terms, and letting $\delta_{i t}$ represent the rate of pre-tax discretionary accruals, we obtain:

$$
P T D A C C_{i t}=\delta_{i t} P I_{i t}
$$

In this study, we ask where earnings are managed. One way to provide evidence on this question is to test whether the discretionary accrual rate on domestic income is different from the discretionary accrual rate on foreign income. That is, we would like to know if $\delta_{i t}$ is the same when pre-tax income is derived from domestic sources as when it is derived from foreign sources. To test this, we can modify Equation (5) as follows:

$$
\operatorname{PTDACC}_{i t}=\alpha_{i t} \text { PIDOM }_{i t}+\beta_{i t} \text { PIFO }_{i t}
$$

\footnotetext{
${ }^{16}$ The breakdown of pre-tax income into pre-tax domestic income and pre-tax foreign income is a required disclosure under U.S. GAAP found in the tax footnote of firm's financial statements to correspond with the breakdown of tax expense into domestic and foreign components.
} 
where $\alpha_{i t}$ represents the rate at which domestic pre-tax income maps into discretionary accruals, and $\beta_{i t}$ represents the rate at which foreign pre-tax income maps into discretionary accruals. Empirical implementation requires dropping the subscripts $i$ and $t$ on the coefficients $\alpha$ and $\beta$ and the inclusion of an error term. We also include an intercept for completeness. Thus, we estimate an OLS regression of the following form:

$$
\operatorname{PTDACC}_{i t}=\gamma+\alpha P I D O M_{i t}+\beta \text { IFO }_{i t}+\epsilon_{i t}
$$

Our first test, for which we have no directional prediction, is whether $\alpha=\beta$, or in words, whether there is a difference between the rate at which PIDOM and PIFO map into PTDACC. We are also interested in the cross sectional determinants of $\alpha$ and $\beta$. In particular, we hypothesize that $\beta$ is a function of the rule of law of the foreign countries in which the firm operates material subsidiaries, and that $\beta$ may also be a function of whether or not the firm operates in tax havens.). We can extend Equation (6) to facilitate these hypotheses as follows:

$$
\begin{gathered}
\alpha_{i t}=\pi_{0}+\pi_{1} \text { RULE OF LAW } \text { LAt }_{i}+\pi_{2} \text { HAVEN INTENSITY }_{i t} \\
+\sum_{k} \pi_{k} \text { CONTROL }_{i t}^{k}
\end{gathered}
$$

and

$$
\begin{gathered}
\beta_{i t}=\omega_{0}+\omega_{1} \text { RULE OF LAW } \text { L }_{i t}+\omega_{2} \text { HAVEN INTENSITY } \\
+\sum_{k} \omega_{k} \text { CONTROL }_{i t}^{k} .
\end{gathered}
$$

Substituting equation (8) and equation (9) into equation (6) gives the following:

$$
\begin{aligned}
& P_{\text {PDACC }}=\pi_{0} \text { PIDOM }_{i t}+\pi_{1} \text { PIDOM }_{i t} * \text { RULE OF LAW } i t+\pi_{2} P_{\text {IDOM }} \text { * } \\
& \text { HAVEN INTENSITY }{ }_{i t}+\sum_{k} \pi_{k} \text { PIDOM }_{i t} * \text { CONTROL }_{i t}^{k}+\omega_{0} P_{\text {IFO }}+ \\
& \omega_{1} \text { PIFO }_{i t} * \text { RULE OF LAW } \text { it }+\omega_{2} \text { PIFO }_{i t} * \text { HAVEN INTENSITY } i t+ \\
& \sum_{k} \omega_{k} \text { PIFO }_{i t} * \text { CONTROL }_{i t}^{k} \text {. }
\end{aligned}
$$


To empirically estimate equation (10), we also add an intercept and an error term:

$$
\begin{aligned}
& \text { PTDACC }_{i t}=\gamma+\pi_{0} \text { PIDOM }_{i t}+\pi_{1} \text { PIDOM }_{i t} * \text { RULEOF LAW } i t+ \\
& \pi_{2} \text { PIDOM }_{i t} * \text { HAVEN INTENSITY }_{i t}+\sum_{k} \pi_{k} \text { PIDOM }_{i t} * \text { CONTROL }_{i t}^{k}+ \\
& \omega_{0} \text { PIFO }_{i t}+\omega_{1} \text { PIFO }_{i t} * \text { RULE OF LAW } i t+\omega_{2} \text { PIFO }_{i t} * \\
& \text { HAVEN INTENSITY } i t+\sum_{k} \omega_{k} P I F O_{i t} * \text { CONTROL }_{i t}^{k}+e_{i t} \text {. }
\end{aligned}
$$

Hypothesis 1 predicts that firms with subsidiaries in countries with a high rule of law will have less earnings management in foreign earnings. That is, Hypothesis 1 predicts that $\omega_{1}<0$. Hypothesis 2 predicts that firms with subsidiaries in tax haven countries will have more earnings management in foreign earnings. That is, Hypothesis 2 predicts that $\omega_{2}>0$.

Table 6 presents estimates of Equation (11), with Panel A estimated over all firm-years and Panel B estimated over firm-years with positive pre-tax foreign and positive pre-tax domestic income. In Panel A of Table 6, Model 1 examines how discretionary accruals are explained by pre-tax domestic income and pre-tax foreign income without control variables. The coefficients on both PIDOM and PIFO are positive and significant, with values of 22.031 and 14.817, respectively. The coefficient on PIDOM is significantly greater than the coefficient on PIFO, as indicated by F-statistic in the bottom row of the table. The interpretation is that, at the mean, a dollar of pre-tax domestic income results in approximately 22 cents of pre-tax discretionary accruals, whereas a dollar of pre-tax foreign income results in approximately 15 cents of pre-tax discretionary accruals. Dollar-for-dollar, this is consistent with domestic income being subject to more earnings management than foreign income.

The results for Model 2 include the control variables from Table 5: SPE INTENSITY, FOREIGNNESS, NCOUNTRIES, SIZE, CPI CHANGE SUB COUNTRIES, GDP CHANGE SUB COUNTRIES, SALES VOLATILITY, and CASH FLOW VOLATILITY. For the sake of brevity the coefficients on those variables are not reported in Table 6 and their presence is instead noted by a 
"YES” in the row labeled "CONTROLS.” Notice, however, that the control variables result in a large increase in explanatory power from an $\mathrm{R}^{2}$ of approximately 21 percent in Model 1 to approximately 31 percent in Model 2. With the controls included, both PIDOM and PIFO remain positive and significant (27.278, and 19.078, respectively).

In Models 3 and 4, we interact PIDOM and PIFO with RULE OF LAW and HAVEN INTENSITY. We expect the effects of rule of law to be concentrated in pre-tax foreign income. Accordingly, we predict a negative coefficient on the interaction of PIFO and RULE OF LAW. We also allow RULE OF LAW to interact with PIDOM for the sake of completeness, but we make no prediction on its sign. Model 3 reveals that the coefficient on PIFO*RULE OF LAW is negative and significant, as predicted (-20.788). This is consistent with pre-tax foreign income being subject to more (less) earnings management when the firm's foreign operations are in countries with relatively weak (strong) rule of law.

To facilitate interpretation of the interaction terms, all variables have been mean centered. Thus, for the mean firm in Model 3, 18.8 cents of each foreign pre-tax dollar maps into a dollar of pre-tax discretionary accruals. A one standard deviation increase in RULE OF LAW is associated with a 10.1 cent per dollar lower rate at which pre-tax foreign income maps into discretionary accruals. ${ }^{17}$ The coefficient on the interaction of RULE OF LAW and PIDOM is also significant, but the effect is much smaller economically. A one standard deviation increase in RULE OF LAW is associated with a four cent per dollar lower rate at which pre-tax domestic income maps into discretionary accruals.

Model 4 includes the interaction of PIDOM and PIFO with HAVEN INTENSITY. As with RULE OF LAW, we expect that the effects of HAVEN INTENSITY will be concentrated in foreign income. We make no prediction for the interaction of HAVEN INTENSITY and domestic

\footnotetext{
${ }^{17}$ Calculated as $-20.768 * 0.487=10.1$.
} 
income. In this specification, the coefficient on PIFO*HAVEN INTENSITY is insignificant. However, because our prediction for HAVEN INTENSITY is most applicable for profitable firms, the interpretation for the full sample is less of a concern. In Model 5 we include all of the interactions at the same time. Consistent with the results in Models 1-4, the coefficient on PIFO*RULE OF LAW is negative and significant (-20.872) but the coefficient on PIFO*HAVEN INTENSITY remains insignificant. The main effects of both PIDOM and PIFO remain positive and significant with values 27.758 and 18.867, respectively.

In Table 6, Panel B, we re-estimate the regressions in Panel A, except we use only the subsample of firms that have positive pre-tax domestic income and positive pre-tax foreign income. As in the Table 5 analysis, we include this test because of evidence that discretionary accruals can be asymmetric with respect to losses (Ball and Shivakumar, 2006) and because our prediction for HAVEN INTENSITY is most applicable for profitable (tax-paying) firms. Model 1 examines how discretionary accruals are explained by pre-tax domestic income and pre-tax foreign income without control variables. The coefficients on both PIDOM and PIFO are positive and significant, with values of 5.517 and 4.984, respectively. In Model 2 we include the control variables SPE INTENSITY, FOREIGNNESS, NCOUNTRIES, SIZE, CPI CHANGE SUB COUNTRIES, GDP CHANGE SUB COUNTRIES, SALES VOLATILITY, and CASH FLOW VOLATILITY. The controls increase the explanatory power of the model and cause the coefficients on both PIDOM and PIFO to increase to 13.060 and 8.197.

Models 3 and 4 consider the effects of interacting PIDOM and PIFO with RULE OF LAW and HAVEN INTENSITY, respectively. We continue to find a negative coefficient on the interaction of PIFO with RULE OF LAW. In contrast to Panel A of Table 6, the coefficient on PIFO*HAVEN INTENSITY is positive and significant as predicted in both Models 4 and 5, 
whereas it was insignificant in Panel A. This indicates that among profitable firms, earnings management of foreign income is increasing in the extent of subsidiaries in tax haven locations.

To graphically illustrate the effect of RULE OF LAW and HAVEN INTENSITY on the mapping of PIFO into PTDACC, we re-estimate the model but replace the continuous variables RULE OF LAW and HAVEN INTENSITY with indicator variables that capture quintiles of RULE OF LAW and HAVEN INTENSITY. The coefficient value for each of the quintiles is then plotted in Figure 2. As the figure shows, the effect of RULE OF $L A W$ is greatest when moving from the first to second quintile, and then continues to strengthen through the fifth quintile. Similarly, the effect of HAVEN INTENSITY is greatest when moving from the first to second quintile of HAVEN INTENSITY, and increasing thereafter, with the largest effect concentrated in the quintile containing the most haven-intense firms.

\subsection{Additional Tests}

\subsubsection{Absolute Value of Discretionary Accruals}

To examine the robustness of the results, we perform a number of additional tests. In this subsection, we change the dependent variable to the absolute value of discretionary accruals (|PTDACC $\mid)$, to capture both income-increasing and income-decreasing earnings management. ${ }^{18}$ Table 7 is the analog to Panel A of Table 5, but with the absolute value of discretionary accruals as the dependent variable. As in the earlier analysis, RULE OF LAW is negatively associated with earnings management, with coefficients of -0.306 in both Model 1 and Model 3. This indicates that firms with subsidiaries in high rule of law countries engage in less earnings management than firms with subsidiaries in low rule of law countries. Unlike Table 5 Panel A, the coefficient on HAVEN INTENSITY is positive and significant, as predicted, with a value of

\footnotetext{
${ }^{18}$ Many studies use the absolute value of discretionary accruals, including Dechow and Dichev (2002), Frankel, Johnson, and Nelson (2002), Klein (2002), Chung and Kallapur (2003), Myers, Myers, and Omer (2003), Leuz, Nanda, and Wysocki (2003), and Bergstresser and Philippon (2006).
} 
0.649 in both Models 2 and 3. We cannot fully explain the economic drivers of a positive relation with the absolute value of discretionary accruals but no relation with signed discretionary accruals. The coefficients on the control variables are generally consistent between Table 7 and Table 5, Panel A in terms of sign and significance. The exceptions are the volatility controls. SALES VOLATILITY was insignificant in Table 5 but is positive and significant in Table 7. CASH FLOW VOLATILITY was negative in Table 5 but is positive in the Table 7 analysis of absolute value of discretionary accruals. Based on Hribar and Nichols (2007), we expect a positive coefficient on both volatility controls in Table 7, where we are explaining the absolute value of discretionary accruals.

Table 8 is the analog to Panel A of Table 6 but with the absolute value of discretionary accruals as the dependent variable. The analysis examines how RULE OF LAW and HAVEN INTENSITY affect the mapping of the absolute value of foreign pre-tax income into the absolute value of discretionary accruals. Model 1 of Table 8 reveals that the coefficients on both $|P I D O M|$ and $|P I F O|$ are positive and significant, with values of 8.913 and 4.215 , respectively. The coefficient on $|P I D O M|$ is significantly greater than the coefficient on $|P I F O|$, as indicated by the bottom row of the table. Model 2 includes the control variables from Table 6 . As in Table 6, the $\mathrm{R}^{2}$ of the models increase substantially with the addition of the control variables. With the controls included, both PIDOM and PIFO remain positive and significant.

In Models 3 and 4, we interact $|P I D O M|$ and $|P I F O|$ with RULE OF LAW, HAVEN INTENSITY, and SPE INTENSITY. As indicated earlier, we expect the effects of foreign rule of law to be concentrated in pre-tax foreign income. Accordingly, we predict a negative coefficient on the interaction of $|P I F O|$ and RULE OF LAW. Model 3 reveals that the coefficient on $|P I F O|^{*} R U L E$ OF LAW is negative and significant, as predicted, at -5.956 . This is consistent 
with pre-tax foreign income being subject to more (less) earnings management when the firm's foreign operations are in countries with relatively weak (strong) rule of law. A one standard deviation increase in RULE OF LAW is associated with a 2.9 cent per dollar lower rate at which pre-tax foreign income maps into discretionary accruals. In contrast to the effect of $R U L E O F$ $L A W$ on management of foreign income, the coefficient on the interaction of RULE OF LAW and $|P I D O M|$ is insignificant, consistent with the rule of law of the firm's foreign operations having little or no effect on the firm's management of domestic income.

Model 4 includes the interaction of $|P I D O M|$ and $|P I F O|$ with HAVEN INTENSITY. As predicted, the coefficient on $|P I F O|{ }^{*} H A V E N$ INTENSITY is positive and significant (10.759), consistent with firms with extensive tax haven subsidiaries engaging in more earnings management of their foreign pre-tax income. A one standard deviation increase in HAVEN INTENSITY is associated with additional discretionary accruals of 1.9 cents per dollar of pre-tax foreign income.

In Model 5 we include all of the interactions at the same time. Consistent with the results in Models 1-4, the coefficient on $|P I F O|^{*} R U L E$ OF LAW is negative and significant (-7.090) and the coefficient on $\mid$ PIFO $\left.\right|^{*} H A V E N$ INTENSITY is positive and significant (13.998). The main effects of both $|P I D O M|$ and $|P I F O|$ remain positive and significant with values 7.853 and 4.309, respectively. Thus, across the tests with the absolute value of discretionary accruals as the dependent variable, the results suggest that earnings management of foreign income is decreasing in the rule of law of the firm's foreign subsidiaries, and increasing in the tax haven intensity of its foreign subsidiaries. Apart from those results, domestic income appears to be managed more than foreign income. 


\subsubsection{Additional Control Variables}

In this subsection, we include additional control variables in the regressions specified in Equation (3) and Equation (11). Specifically, in untabulated results, we also include the following control variables: firm age, leverage, the market to book ratio, the market value of equity, a proxy for capital intensity, a proxy for intangible intensity, and a variable that captures the fraction of loss years over the firm's past ten fiscal years. These variables are drawn from prior research that uses similar dependent variables (e.g. Hribar and Nichols, 2007; Francis et al., 2005). Results remain statistically and economically similar with the inclusion of these variables. We also find that the inclusion of two-digit SIC code fixed effects does not alter our findings materially.

\subsubsection{Controlling for Performance}

Kothari et al. (2007) describes how performance matching can improve modified discretionary accruals models by controlling for extreme performance that makes estimation of discretionary accruals difficult. Dechow et al. (2011) presents a new method of improving the modified Jones model based on researcher-predicted timing of accrual reversals. Both of these adjustments are only improvements to the model under certain conditions. For performance matching, if performance is correlated with earnings management, the power of the model is actually reduced as it throws the proverbial baby out with the bathwater. For the Dechow et al. (2011) model, the modified Jones model's ability to detect discretionary accruals is only improved if the researcher has an ex ante prediction of when the managed accruals will reverse.

We control for performance by adding return-on-assets to our regression models in untabulated tests. The results are qualitatively the same for our test variables and the inferences remain the same, except for the coefficient on HAVEN INTENSITY in Table 5, Panel B, which 
becomes insignificant. We do not have predictions about when managed accruals will reverse in our setting and thus do not test for reversals in our analyses.

\subsubsection{Alternative Measures of Rule of Law and Haven Intensity}

We test the robustness of our results to different definitions of our main variables. First, we replace HAVEN INTENSITY throughout the study with the natural log of the number of tax haven countries in which the firm operates, and find similar results. Second, we replace RULE of $L A W$ throughout the study with a variable that counts the number of "corrupt" countries in which the firm operates, and we find that firms in more corrupt countries engage in more foreign earnings management. ${ }^{19}$ In sum, results do not appear to be highly dependent on specific definitions of tax haven intensity or rule of law.

\subsubsection{Restatements}

In further robustness tests, we replace pre-tax discretionary accruals from Equation (3) with a binary variable that equals one if the firm restated its financial statements for that year. Compared to discretionary accruals, restatements have the advantage that they are independent of the researcher, as they are not based on a researcher-generated model of accruals. However, restatements have two main disadvantages. First, restatements will not capture within-GAAP earnings management. Second, and most importantly, for a restatement to occur the GAAP violation must be discovered. Thus, the most successful earnings management may never result in a restatement, either because it was within GAAP to begin with or because it was well hidden and never discovered. Since variation in the risk of detection across foreign operations is at the heart of this paper's hypotheses, restatements are less than ideal for this paper (the same would hold true for SEC AAERs).

\footnotetext{
${ }^{19}$ A corrupt country was defined to be any country in the most corrupt quartile of the World Bank's Corruption
} Index. 
Because the dependent variable is an indicator variable, we estimate the model with logistic regression. We include a number of additional controls that have been used in prior research examining accounting restatements and fraud. ${ }^{20}$ Restatements are gathered from the Government Accountability Office (GAO), and cover the years 1995-2005. The new data requirements (the restatement variable plus the additional controls) reduce the sample size to 6,699 firm-years, of which 269 are restatement firm-years.

In Table 9, we report results from the logistic regression. Consistent with our predictions, we find that increases in RULE OF LAW significantly reduce the likelihood of a restatement. The unconditional probability of restatement in our sample given the explanatory variables is about four percent. A one standard deviation improvement in RULE OF LAW decreases the probability of a restatement by 0.9 percent to 3.1 percent. On the other hand, we find no evidence that HAVEN INTENSITY is associated with restatements.

Current research suggests that propensity score matching can improve the reliability of results in observational studies (Armstrong, Jagolinzer, and Larcker, 2010). Accordingly, we reestimate the restatement tests using a propensity score matching approach, as follows. Among firm-years that have restatement data, we keep only those observations in the lowest quintile of RULE OF LAW or the highest two quintiles of RULE OF LAW. Firm-years that are in the lowest quintile of RULE OF LAW are assigned to the "treatment" group, and firm-years that are in the highest two quintiles of RULE OF LAW are assigned to the potential "control” group. We then fit a logistic regression predicting the treatment as a function of the control variables from Table 5. We use the predicted probability of receiving the treatment to match treatment firm-years to

\footnotetext{
${ }^{20}$ The additional control variables include: change in receivables, change in inventory, change in cash sales, change in return on assets, change in the number of employees, the level of "soft" assets, an indicator for whether the firm issued debt or equity in the period, an indicator for whether the firm has outstanding leases, a measure of ex-ante financing needs, Altman's Z, and industry fixed effects. See Dechow et al., 2011 for detailed definitions of these variables.
} 
control firm-years. Once treatment and control firm-years are matched, we compare the frequency of observed restatements across the two groups. ${ }^{21}$ Results are presented in Table 10, Panel A. Of the 1,062 firm-years with subsidiaries in relatively strong RULE OF LAW countries, we find that 12 resulted in restated earnings. Of the 1,062 firm-years with subsidiaries in relatively weak RULE OF LAW countries, we find that 57 resulted in restated earnings. The difference is highly significant. This finding is consistent with the finding in Table 9 that firms with subsidiaries in countries with a weak rule of law are more likely to restate earnings.

In Table 10, Panel B, we examine the effectiveness of the matches. With each variable, we present two rows - the top row presents the mean of the variable for the treatment and control groups prior to the match (labeled “pre-match”) and the second row presents the mean of the variable for the treatment and control groups after the match is made. We see substantial tightening of the control variables across the two groups post-match relative to pre-match, though many of the variables remain significant. This suggests that the matches were effective, though not perfect in eliminating the effects of the covariates.

In Table 11, we repeat the exercise, but for HAVEN INTENSITY. Unlike the tests in Table 10, we find no evidence that firms with more intense tax haven usage are more likely to restate financial statements. Again, this is consistent with the logistic regression results in Table 9. Overall, the tests on the restatement sample indicate that having subsidiaries in weak rule of law countries is associated with a higher likelihood of restatement, whereas having subsidiaries in tax havens is not associated with the likelihood of restatement.

\footnotetext{
${ }^{21}$ Not every treatment firm will match with a control firm, and the propensity score approach involves a trade-off. If the matching process is relaxed so that more firms match, then the resulting matches will be less precise. Conversely, if the matching is required to be very precise, then there will be fewer successful matches.
} 


\section{Conclusions}

We examine the location of earnings management across domestic and foreign income for a sample of 2,067 U.S. multinational firms (11,077 firm-years) over the years 1994-2009. We report three main findings. First, we find that domestic income tends to be managed more than foreign income, on average. Second, we predict and find that firms with extensive foreign subsidiaries in countries with a low rule of law engage in more earnings management than other firms, and the earnings management is concentrated in foreign income. Third, we find that profitable firms with a relatively high proportion of subsidiaries in tax havens manage earnings more than other firms, as measured by discretionary accruals, and that the incremental effect is also concentrated in foreign income. Together, these results provide initial evidence about where firms manage earnings.

All studies are subject to certain caveats, and this study is no exception. In an ideal experiment we could assign firms randomly to do business in different locals, with varying levels of rule of law and taxation, and then observe how their earnings management changed with the footprint of their operations around the world. Like most archival research we do not have the luxury of random assignment, and thus we have the limitations that come with observing data as they naturally occur.

This paper contributes to the long line of research on earnings management by providing initial evidence on where firms manage earnings, a question that is for the most part unexplored. In addition, our study is an early step in the literature focused on looking within multinational firms rather than only across firms. We look forward to further inquiries in the future. 


\section{References}

Aiken, L., and S. West. Multiple Regression: Testing and Interpreting Interactions. Thousand Oaks, CA: Sage, 1991.

Armstrong, Jagolinzer, and Larcker, 2010. Chief Executive Officer Equity Incentives and Accounting Irregularities. Journal of Accounting Research 48 (May): 225-271.

Ball, R and L. Shivakumar. 2006. The role of accruals in asymmetrically timely gain and loss recognition. Journal of Accounting Research 44 (May): 207-242.

Berger, P. and R. Hann. 2003. The impact of SFAS No. 131 on information and monitoring. Journal of Accounting Research 41 (May): 163-197.

Bergstresser, D. and T. Philippon. 2006. CEO incentives and earnings management. Journal of Financial Economics 80 (June): 511-529.

Beuselinck, C., M. Deloof, and A. Vanstraelen. 2010. Earnings Management Contagion in Multinational Corporations. Tilburg University and Antwerp University working paper.

Bodnar, G. and J. Weintrop. 1997. The valuation of the foreign income of US multinational firms: a growth opportunities perspective. Journal of Accounting and Economics 24(December): 69-97.

Bowen, R. E. W. Noreen, and J. M. Lacey. 1981. Determinants of the corporate decision to capitalize interest. Journal of Accounting and Economics 3 (August): 151-179.

Burgstahler, D. and I. Dichev. 1997. Earnings management to avoid earnings decreases and losses. Journal of Accounting and Economics 24(1): 99-126.

Chung, H. and S. Kallapur. 2003. Client importance, nonaudit services, and abnormal accruals. The Accounting Review 78: 931-955.

Committee of Sponsoring Organizations of the Treadway Commission (COSO). 2010. Fraudulent financial reporting: An analysis of U.S. public companies, 1998-2007.

Dechow , P. M. and I. Dichev. 2002. The quality of accruals and earnings: The role of accrual estimation errors. The Accounting Review 77 (Supplement): 35-59.

Dechow, P. M., W. Ge, C. Larson, and R. Sloan. 2011. Predicting Material Accounting Restatements. Contemporary Accounting Research 28: 17-82.

Dechow, P. M., W. Ge and C. Schrand. 2010. Understanding earnings quality: A review of their proxies, their determinants and their consequences. Journal of Accounting and Economics 50: 344-401. 
Dechow, P. M. and D. J. Skinner. 2000. Earnings management: Reconciling the views of accounting academics, practitioners, and regulators. Accounting Horizons 14: 235-250.

Dechow, P. M., R. G. Sloan, and A. P. Sweeney. 1995. Detecting earnings management. The Accounting Review 70: 193-225.

DeFond, M., M. Hung, and R. Trezevant. 2007. Investor Protection and the Information Content of Annual Earnings Announcements: International Evidence. Journal of Accounting and Economics 43: 37-67.

DeFond, M., and J. Jiambalvo. 1994. Debt Covenant Violation and Manipulation of Accruals. Journal of Accounting Research 17: 145-176.

Desai, M. and D. Dharmapala, 2006. Corporate tax avoidance and high-powered incentives. Journal of Financial Economics 79, 145-179.

Desai, M., I, Dyck and L, Zingales, 2007. Theft and taxes. Journal of Financial Economics 84, 591-623.

Dichev, I., and D. Skinner. 2002. Large-Sample Evidence on the Debt Covenant Hypothesis. Journal of Accounting Research, 40: 1091-1123.

Doyle, J., W. Ge and S. McVay, 2007. Accruals quality and internal control over financial reporting, The Accounting Review 82, pp. 1141-1170.

Durnev, A., T. Li, and M. Magnan. 2009. The Governance of Offshore Firms: Implications for Financial Reporting. McGill University, University of Windsor, and Concordia University working paper.

Duru, A. and D. Reeb, 2002. International Diversification and Analysts’ Forecast Accuracy and Bias. The Accounting Review 77(2): 415-433.

Dyreng, S. and B. Lindsey. 2009. Using Financial Accounting Data to Examine the Effect of Foreign Operations Located in Tax Havens and Other Countries on U.S. Multinational Firms’ Tax Rates. Journal of Accounting Research 47(December): 1283-1316.

Dyreng, S., W. Mayew, and C. Willams. 2010. Religious Social Norms and Corporate Financial Reporting. Duke University and University of Michigan working paper.

Erickson, M., M. Hanlon and E. Maydew. 2004. How much will firms pay for earnings that do not exist? Evidence of taxes paid on allegedly fraudulent earnings. The Accounting Review 79: 387-408.

Fan, N. 2008. A study of foreign earnings management using an empirical distribution approach. Unpublished dissertation, University of Texas at Arlington. 
Fields, T. D., T. Z. Lys, and L. Vincent. 2001. Empirical research on accounting choice. Journal of Accounting \& Economics 31: 255-307.

Frankel, R. M., M. F. Johnson, and K. K. Nelson. 2002. The relation between auditors' fees for nonaudit services and earnings management. The Accounting Review 77 (Supplement): 71-105.

Goelzer, D. Seven years of the Public Company Accounting Oversight Board - What has been accomplished and what remains to be done? Speech before the AICPA Conference, Washington, D.C., December 7, 2009.

Golden. T., S. Skalak, and M. Clayton. 2006. A guide to forensic accounting. Wiley.

Grullon, G., G. Kanatas, and J. Weston. Religion and Corporate (Mis)Behavior. Rice University Working Paper, 2010.

Hagerman, R. L. and M. E. Zmijewski. 1979. Some economic determinants of accounting policy choice. Journal of Accounting and Economics 1(August): 141-161.

Healy, P. 1985. The effect of bonus schemes on accounting decisions. Journal of Accounting and Economics 7: 85-107.

Healy, P., and J. Wahlen. 1999. A review of the earnings management literature and its implications for standard setting. Accounting Horizons 13(4): 365-383.

Holthausen, R. W. 1981. Evidence on the effect of bond covenants and management compensation contracts on the choice of accounting techniques: The case of the depreciation switch-back. Journal of Accounting and Economics 3: 73-109.

Hope, O.-K., T.Kang, W. Thomas, and F. Vasvari. 2008. Pricing and Mispricing effects of SFAS No. 131. Journal of Business Finance and Accounting 35: 281-306.

Hribar, P. and D. C. Nichols, 2007. The use of unsigned earnings quality measures in tests of earnings management. Journal of Accounting Research 45, 1017-1053.

Jones, J., 1991. Earnings management during import relief investigations. Journal of Accounting Research 29, 193-228

Kedia, S. and S. Rajgopal. 2011. Do the SEC's enforcement preferences affect corporate misconduct? Journal of Accounting and Economics 51(3): 259-273.

Klein, A. 2002. Audit committee, board of director characteristics, and earnings management. Journal of Accounting and Economics 33: 375-400.

Leuz, C., D. Nanda and P. Wysocki, 2003. Earnings management and investor protection: an international comparison. Journal of Financial Economics 69: 505-527 
McGuire, S., T. Omer, and N. Sharp. The Impact of Religion on Financial Reporting Irregularities. Texas A\&M Working Paper, 2010.

Miedema, D. 2008. FACTBOX - tax havens of the world. Reuters: March 4.

Mishkin, F. 1983. A rational expectations approach to macroeconometrics: Testing policy effectiveness and efficient markets models. Chicago, IL: University of Chicago Press for the National Bureau of Economic Research.

Myers, J. N., L. A. Myers, and T. C. Omer. 2003. Exploring the term of the auditor-client relationship and the quality of earnings: A case for mandatory auditor rotation? The Accounting Review 78(July): 779799.

Petersen, M. A. 2009. Estimating standard errors in finance panel data sets: Comparing approaches. Review of Financial Studies 22: 435-480.

Schipper, K. 1989. Commentary: Earnings management. Accounting Horizons (December): 91102.

Sweeney, A. 1994. Debt-covenant Violations and Managers’ Accounting Responses. Journal of Accounting and Economics 17: 281-308.

Thomas, W. 1999. A test of the market's mispricing of domestic and foreign earnings. Journal of Accounting and Economics 28: 243-268.

Watts, R. and J. Zimmerman. 1978. Towards a positive theory of the determination of accounting standards. The Accounting Review (January): 112-134. 


\section{Table 1 \\ Sample Selection}

Criteria

U.S. Corporations covered by Compustat between 1994 and 2009 with total assets greater than $\$ 1$ million and non-missing values of the following variables: OANCF, TXPD, SALE, RECCH, PPEGT, and PI

With data necessary to compute Jones Model Accruals (including lagged assets for the scaler, and 10 industry-year observations to estimate the equation

With non-missing values of PIDOM and PIFO

With non-missing values of Rule of Law, Haven Intensity, SPE

Intensity, CPI, GDP, Foreignness, cash flow volatility, and sales volatility
Firms

10,710

78,448

10,412

69,819

6,832

32,734

2,067

11,077

Notes: This table explains the sample selection criteria used in the study. Variables referred to above are defined in Table 3 and in Section 3.1. 
Table 2

Sample Frequency by Industry

\begin{tabular}{|c|c|c|c|c|}
\hline Industry & Sample Firms & $\begin{array}{c}\text { Pct of Sample } \\
\text { Firms }\end{array}$ & $\begin{array}{l}\text { Compustat } \\
\text { Firms }\end{array}$ & $\begin{array}{c}\text { Pct of } \\
\text { Compustat } \\
\text { Firms }\end{array}$ \\
\hline Automobiles and Trucks & 58 & $2.81 \%$ & 173 & $1.36 \%$ \\
\hline Beer and Liquor & 5 & 0.24 & 38 & 0.30 \\
\hline Printing and Publishing & 30 & 1.45 & 160 & 1.26 \\
\hline Business Equipment & 438 & 21.19 & 1,650 & 12.98 \\
\hline Aircraft, Ships, and Railroad Equipment & 17 & 0.82 & 76 & 0.60 \\
\hline Chemicals & 80 & 3.87 & 243 & 1.91 \\
\hline Apparel & 41 & 1.98 & 160 & 1.26 \\
\hline Construction & 56 & 2.71 & 390 & 3.07 \\
\hline Coal & 1 & 0.05 & 32 & 0.25 \\
\hline Electrical Equipment & 55 & 2.66 & 183 & 1.44 \\
\hline Fabricated Products & 160 & 7.74 & 452 & 3.56 \\
\hline Food Products & 37 & 1.79 & 281 & 2.21 \\
\hline Recreation & 42 & 2.03 & 453 & 3.56 \\
\hline Health Care & 160 & 7.74 & 1,634 & 12.86 \\
\hline Consumer Goods & 53 & 2.56 & 223 & 1.75 \\
\hline Restaurants, Hotels, Motels & 14 & 0.68 & 303 & 2.38 \\
\hline Mining & 14 & 0.68 & 110 & 0.87 \\
\hline Oil & 76 & 3.68 & 572 & 4.50 \\
\hline Other & 64 & 3.10 & 651 & 5.12 \\
\hline Paper products & 57 & 2.76 & 167 & 1.31 \\
\hline Retail & 40 & 1.94 & 712 & 5.60 \\
\hline Services & 375 & 18.14 & 2,258 & 17.77 \\
\hline Steel & 40 & 1.94 & 165 & 1.30 \\
\hline Telecommunications & 36 & 1.74 & 640 & 5.04 \\
\hline Transportation & 31 & 1.50 & 341 & 2.68 \\
\hline Textiles & 17 & 0.82 & 76 & 0.60 \\
\hline Wholesale & 70 & 3.39 & 567 & 4.46 \\
\hline Total & 2,067 & $100.00 \%$ & 12,710 & $100.00 \%$ \\
\hline
\end{tabular}

Notes: This table presents the Fama-French 30 industry composition of the sample, compared to all US incorporated firms in Compustat during the sample time period with at least one year of non-missing assets. The financial and utility industries are dropped because we eliminate regulated industries from the sample. Of the 14 firms in Compustat in the tobacco industry, none fulfill all our sample selection criteria, so the industry is dropped from the table. Thus, the table has data on 27 industries. 
Table 3

Descriptive Statistics

\begin{tabular}{lcccccc} 
NAME & N & MEAN & STD & P25 & P50 & P75 \\
\hline PTDACC & 11,077 & 0.003 & 0.099 & -0.030 & 0.011 & 0.050 \\
IPTDACCI & 11,077 & 0.064 & 0.076 & 0.019 & 0.041 & 0.078 \\
PIDOM & 11,077 & 0.026 & 0.147 & -0.015 & 0.036 & 0.090 \\
PIFO & 11,077 & 0.028 & 0.062 & 0.003 & 0.019 & 0.048 \\
RULE OF LAW & 11,077 & 1.065 & 0.487 & 0.780 & 1.087 & 1.406 \\
HAVEN INTENSITY & 11,077 & 0.177 & 0.179 & 0.038 & 0.146 & 0.250 \\
SPE INTENSITY & 11,077 & 0.058 & 0.221 & 0.000 & 0.000 & 0.050 \\
FOREIGNNESS & 11,077 & 0.381 & 0.224 & 0.208 & 0.358 & 0.519 \\
CASH FLOW VOLATILITY & 11,077 & 0.062 & 0.068 & 0.028 & 0.045 & 0.073 \\
SALES VOLATILITY & 11,077 & 0.232 & 0.267 & 0.096 & 0.165 & 0.279 \\
NCOUNTRIES & 11,077 & 2.348 & 0.919 & 1.609 & 2.398 & 3.045 \\
SIZE & 11,077 & 6.716 & 1.805 & 5.523 & 6.676 & 7.872 \\
CPI CHANGE SUB COUNTRIES & 11,077 & 5.205 & 18.087 & 2.113 & 3.003 & 4.586 \\
GDP CHANGE SUB COUNTRIES & 11,077 & 3.444 & 1.672 & 2.300 & 3.494 & 4.570 \\
\hline
\end{tabular}

Notes: This table contains descriptive statistics for variables used in our study. The sample consists of 11,077 observations, selected as outlined in Table 1. PTDACC is pre-tax discretionary accruals, calculated using the modified Jones model using pre-tax accruals instead of total accruals. The model is estimated separately for each two-digit SIC code and year for which there are at least 10 observations. $|P T D A C C|$ is the absolute value of pre-tax discretionary accruals. PIDOM is pre-tax domestic income from Compustat. PIFO is pre-tax foreign income from Compustat. RULE OF LAW is the average rule of law of the countries in which the firm operates. Rule of law scores for each country are obtained from the World Bank Governance Indicators. HAVEN INTENSITY is the number of countries in which the firm discloses a subsidiary that are tax havens divided by the total number of countries in which the firm discloses a subsidiary. A country is designated as tax haven if it appears on at least two of the four lists of tax havens found at http://www.globalpolicy.org. We use the lists as reported on March 4, 2008 as per Dyreng and Lindsey (2009). SPE INTENSITY is the number of subsidiaries that are LLCs, LLPs, or Trusts divided by the total number of subsidiaries. FOREIGNNESS is foreign sales from Compustat geographic segment data divided by total SALES from Compustat. CASH FLOW VOLATILITY is the moving 5-year standard deviation of pre-tax cash flow from operations (i.e. CSHO+TXPD-XIDOC), each year running from year t-4 to year t. $S A L E S$ VOLATILITY is the moving 5-year standard deviation of SALES from Compustat each year running from year t-4 to year t. NCOUNTRIES is the log of the total number of countries in which the firm discloses a subsidiary. SIZE is the log of total assets, CPI CHANGE SUB COUNTRIES is the average change in consumer price index for the countries in which the firm discloses material subsidiaries. GDP CHANGE SUB COUNTRIES is the average change in GDP for the countries in which the firm discloses material subsidiaries. Data on CPI and GDP are gathered from the World Economic Outlook Database, April 2010 edition, available from the International Monetary Fund. PTDACC, PIDOM, and PIFO are scaled by total assets at the beginning of the year. 


\section{Table 4}

\section{Correlations}

\begin{tabular}{|c|c|c|c|c|c|c|c|c|c|c|c|c|c|c|}
\hline & 1 & 2 & 3 & 4 & 5 & 6 & 7 & 8 & 9 & 10 & 11 & 12 & 13 & 14 \\
\hline 1 PTDACC & & $-0.29^{*}$ & $0.51^{*}$ & $0.22^{*}$ & $-0.06^{*}$ & -0.02 & $0.02^{*}$ & 0.02 & $-0.06^{*}$ & $-0.04^{*}$ & $0.04^{*}$ & $0.06^{*}$ & 0.01 & 0.00 \\
\hline $2 \mid$ PTDACC $\mid$ & $0.13^{*}$ & & $-0.33^{*}$ & $-0.14^{*}$ & $0.06^{*}$ & $0.04^{*}$ & -0.01 & 0.01 & $0.29 *$ & $0.22^{*}$ & $-0.14^{*}$ & $-0.21^{*}$ & $-0.03^{*}$ & $-0.07^{*}$ \\
\hline 3 PIDOM & $0.31^{*}$ & $-0.12^{*}$ & & $0.14^{*}$ & $-0.03^{*}$ & -0.01 & 0.01 & $-0.13^{*}$ & $-0.14^{*}$ & $-0.04^{*}$ & $0.10^{*}$ & $0.21^{*}$ & $0.02^{*}$ & $0.07^{*}$ \\
\hline 4 PIFO & $0.17^{*}$ & $-0.11^{*}$ & $0.23^{*}$ & & $-0.11^{*}$ & $0.06^{*}$ & $-0.04^{*}$ & $0.24^{*}$ & -0.01 & 0.02 & $0.20^{*}$ & $0.20^{*}$ & 0.01 & $0.09 *$ \\
\hline 5 RULE OF LAW & $-0.05^{*}$ & $0.07^{*}$ & -0.00 & $-0.15^{*}$ & & $-0.04^{*}$ & -0.01 & $-0.11^{*}$ & $0.10^{*}$ & $0.06^{*}$ & $-0.33^{*}$ & $-0.27^{*}$ & $-0.11^{*}$ & $-0.28^{*}$ \\
\hline 6 HAVEN INTENSITY & -0.01 & 0.01 & -0.01 & $0.11^{*}$ & $-0.10^{*}$ & & $-0.04^{*}$ & $0.08^{*}$ & $0.08^{*}$ & $0.05^{*}$ & $0.04^{*}$ & $0.05^{*}$ & $-0.03^{*}$ & $0.13^{*}$ \\
\hline 7 SPE INTENSITY & $0.02^{*}$ & $-0.05^{*}$ & -0.00 & 0.01 & $-0.19^{*}$ & $0.04^{*}$ & & $-0.10^{*}$ & $-0.04^{*}$ & $-0.02^{*}$ & $-0.13^{*}$ & $0.05^{*}$ & $-0.02^{*}$ & -0.01 \\
\hline 8 FOREIGNNESS & 0.01 & -0.00 & $-0.21^{*}$ & $0.36^{*}$ & $-0.14^{*}$ & $0.13^{*}$ & $-0.08^{*}$ & & $0.03^{*}$ & $-0.04^{*}$ & $0.28^{*}$ & $0.05^{*}$ & $-0.02^{*}$ & $0.06^{*}$ \\
\hline 9 CASH FLOW VOLATILITY & $-0.07^{*}$ & $0.25^{*}$ & 0.01 & $-0.05^{*}$ & $0.16^{*}$ & $0.07^{*}$ & $-0.15^{*}$ & 0.01 & & $0.43^{*}$ & $-0.20^{*}$ & $-0.37^{*}$ & $-0.02^{*}$ & 0.00 \\
\hline 10 SALES VOLATILITY & $-0.02^{*}$ & $0.19^{*}$ & $0.09^{*}$ & -0.01 & $0.11^{*}$ & 0.01 & $-0.09^{*}$ & $-0.09^{*}$ & $0.44^{*}$ & & $-0.11^{*}$ & $-0.23^{*}$ & -0.02 & 0.01 \\
\hline 11 NCOUNTRIES & $0.02^{*}$ & $-0.13^{*}$ & $0.08^{*}$ & $0.33^{*}$ & $-0.41^{*}$ & $0.25^{*}$ & $0.14^{*}$ & $0.35^{*}$ & $-0.24^{*}$ & $-0.14^{*}$ & & $0.55^{*}$ & $0.06^{*}$ & $0.08^{*}$ \\
\hline 12 SIZE & $0.02^{*}$ & $-0.20^{*}$ & $0.17^{*}$ & $0.27^{*}$ & $-0.33^{*}$ & $0.14^{*}$ & $0.31^{*}$ & $0.09^{*}$ & $-0.39^{*}$ & $-0.27^{*}$ & $0.56^{*}$ & & $0.07^{*}$ & $0.07^{*}$ \\
\hline 13 CPI CHANGE SUB COUNTRIES & $0.04^{*}$ & $-0.05^{*}$ & $0.06^{*}$ & $0.15^{*}$ & $-0.64^{*}$ & 0.01 & $0.10^{*}$ & $0.04^{*}$ & $-0.20^{*}$ & $-0.10^{*}$ & $0.41^{*}$ & $0.35^{*}$ & & $0.02^{*}$ \\
\hline 14 GDP CHANGE SUB COUNTRIES & $-0.03^{*}$ & $-0.09^{*}$ & $0.07^{*}$ & $0.11^{*}$ & $-0.28^{*}$ & $0.15^{*}$ & $0.04^{*}$ & $0.06^{*}$ & -0.02 & -0.00 & $0.12^{*}$ & $0.10^{*}$ & $0.06^{*}$ & \\
\hline
\end{tabular}

Notes: This table presents the bivariate Pearson (above the diagonal) and Spearman (below the diagonal) correlations. All variables are defined in Table 3. Sample selection criteria are in Table $1 . *$ indicates significance at the $5 \%$ level or better. 
Table 5

Discretionary Accruals as a Function of Rule of Law, Tax Haven Intensity, and Controls

Panel A: Full Sample - Profit and Loss Firm-years

\begin{tabular}{|c|c|c|c|c|}
\hline & Prediction & Model 1 & Model 2 & Model 3 \\
\hline \multirow[t]{2}{*}{ INTERCEPT } & & $4.024^{* * *}$ & $2.760^{* * *}$ & $4.027^{* * *}$ \\
\hline & & $(7.97)$ & $(7.96)$ & $(7.99)$ \\
\hline \multirow[t]{2}{*}{ RULE OF LAW } & $(-)$ & $-0.687^{* * *}$ & & $-0.688^{* * *}$ \\
\hline & & $(-3.89)$ & & $(-3.90)$ \\
\hline \multirow[t]{2}{*}{ HAVEN INTENSITY } & $(+)$ & & -0.104 & -0.127 \\
\hline & & & $(-0.34)$ & $(-0.40)$ \\
\hline \multirow[t]{2}{*}{ SPE INTENSITY } & & $0.699^{* * *}$ & $0.745^{* * *}$ & $0.697^{* * *}$ \\
\hline & & $(3.03)$ & $(3.00)$ & $(3.02)$ \\
\hline \multirow[t]{2}{*}{ FOREIGNNESS } & & 0.287 & 0.300 & 0.295 \\
\hline & & $(0.77)$ & $(0.79)$ & $(0.79)$ \\
\hline \multirow[t]{2}{*}{ NCOUNTRIES } & & 0.061 & 0.151 & 0.060 \\
\hline & & $(0.72)$ & $(1.69)$ & $(0.72)$ \\
\hline \multirow[t]{2}{*}{ SIZE } & & $-0.131^{* * *}$ & $-0.111^{* *}$ & $-0.130^{* *}$ \\
\hline & & $(-3.00)$ & $(-2.50)$ & $(-2.95)$ \\
\hline \multirow[t]{2}{*}{ CPI CHANGE SUB COUNTRIES } & & -0.002 & -0.001 & -0.002 \\
\hline & & $(-1.48)$ & $(-1.06)$ & $(-1.49)$ \\
\hline \multirow[t]{2}{*}{ GDP CHANGE SUB COUNTRIES } & & $-0.247^{* *}$ & $-0.191^{*}$ & $-0.246^{* *}$ \\
\hline & & $(-2.54)$ & $(-2.09)$ & $(-2.52)$ \\
\hline \multirow[t]{2}{*}{ SALES VOLATILITY } & & -0.253 & -0.261 & -0.250 \\
\hline & & $(-0.75)$ & $(-0.76)$ & $(-0.74)$ \\
\hline \multirow[t]{2}{*}{ CASH FLOW VOLATILITY } & & $-10.659^{* * *}$ & $-10.916^{* * *}$ & $-10.603^{* * *}$ \\
\hline & & $(-6.86)$ & $(-7.09)$ & $(-6.87)$ \\
\hline $\mathrm{N}$ & & 11,077 & 11,077 & 11,077 \\
\hline ADJRSQ & & 0.019 & 0.016 & 0.019 \\
\hline
\end{tabular}

Notes: This table presents estimates from Equation (3): PTDACC $i t=\alpha_{0}+\alpha_{1}$ HAVEN INTENSITY $_{i t}+$ $\alpha_{2} R U L E O F L A W_{i t}+\sum \alpha_{k} C O N T R O L_{i t}^{k}+\epsilon_{i t}$. Each of the variables shown in the table is defined in Table 3. Tstatistics, shown in parentheses below the coefficient estimates, are based on standard errors that are clustered by firm and year. One tailed tests of significance are used where a signed prediction has been made. ***, **, and * represent statistical significance at the $1 \%, 5 \%$, and $10 \%$ levels, respectively. 
Table 5 (continued)

Discretionary Accruals as a Function of Rule of Law, Tax Haven Intensity, and Controls

Panel B: Sub-sample of Firm-Years with Positive Pre-tax Domestic Income and Positive Pre-tax Foreign Income

\begin{tabular}{|c|c|c|c|c|}
\hline & Prediction & Model 1 & Model 2 & Model 3 \\
\hline INTERCEPT & & $\begin{array}{l}7.168^{* * *} \\
(7.59)\end{array}$ & $\begin{array}{l}5.329^{* * *} \\
(9.20)\end{array}$ & $\begin{array}{l}7.170^{* * *} \\
(7.65)\end{array}$ \\
\hline RULE OF LAW & $(-)$ & $\begin{array}{l}-0.980^{* * *} \\
(-3.62)\end{array}$ & & $\begin{array}{l}-0.981^{* * *} \\
(-3.61)\end{array}$ \\
\hline HAVEN INTENSITY & $(+)$ & & $\begin{array}{l}0.828^{* *} \\
(1.87)\end{array}$ & $\begin{array}{l}0.836^{* *} \\
(1.89)\end{array}$ \\
\hline SPE INTENSITY & & $\begin{array}{l}1.371^{* * *} \\
(4.17)\end{array}$ & $\begin{array}{l}1.608^{* * *} \\
(4.16)\end{array}$ & $\begin{array}{l}1.373^{* * *} \\
(4.17)\end{array}$ \\
\hline FOREIGNNESS & & $\begin{array}{l}2.314^{* * *} \\
(5.52)\end{array}$ & $\begin{array}{l}2.157^{* * *} \\
(5.18)\end{array}$ & $\begin{array}{l}2.259^{* * *} \\
(5.36)\end{array}$ \\
\hline NCOUNTRIES & & $\begin{array}{l}-0.261^{* *} \\
(-2.59)\end{array}$ & $\begin{array}{c}-0.089 \\
(-0.96)\end{array}$ & $\begin{array}{l}-0.255^{* *} \\
(-2.53)\end{array}$ \\
\hline SIZE & & $\begin{array}{l}-0.311^{* * *} \\
(-5.88)\end{array}$ & $\begin{array}{l}-0.301^{* * *} \\
(-5.74)\end{array}$ & $\begin{array}{l}-0.322^{* * *} \\
(-6.09)\end{array}$ \\
\hline CPI CHANGE SUB COUNTRIES & & $\begin{array}{l}-0.006^{* *} \\
(-2.46)\end{array}$ & $\begin{array}{l}-0.004^{* *} \\
(-2.78)\end{array}$ & $\begin{array}{l}-0.006^{* *} \\
(-2.39)\end{array}$ \\
\hline GDP CHANGE SUB COUNTRIES & & $\begin{array}{l}-0.362^{* *} \\
(-2.66)\end{array}$ & $\begin{array}{l}-0.292^{* *} \\
(-2.35)\end{array}$ & $\begin{array}{l}-0.372^{* *} \\
(-2.75)\end{array}$ \\
\hline SALES VOLATILITY & & $\begin{array}{c}0.543 \\
(1.14)\end{array}$ & $\begin{array}{c}0.442 \\
(0.93)\end{array}$ & $\begin{array}{c}0.495 \\
(1.03)\end{array}$ \\
\hline CASH FLOW VOLATILITY & & $\begin{array}{l}-19.339^{* * *} \\
(-7.86)\end{array}$ & $\begin{array}{l}-19.798^{* * *} \\
(-8.18)\end{array}$ & $\begin{array}{l}-19.647^{* * *} \\
(-8.12)\end{array}$ \\
\hline $\mathrm{N}$ & & 6,529 & 6,529 & 6,529 \\
\hline ADJRSQ & & 0.060 & 0.053 & 0.061 \\
\hline
\end{tabular}

Notes: This table presents estimates from Equation (3): PTDACC $C_{i t}=\alpha_{0}+\alpha_{1}$ HAVEN INTENSITY $_{i t}+$ $\alpha_{2} R U L E O F L A W_{i t}+\sum \alpha_{k} C_{O N T R O L}^{k}+\epsilon_{i t}$. Only observations with positive domestic and foreign pre-tax incomes are included. Each of the variables shown in the table is defined in Table 3. T-statistics, shown in parentheses below the coefficient estimates, are based on standard errors that are clustered by firm and year. One tailed tests of significance are used where a signed prediction has been made. ${ }^{* *},{ }^{* *}$, and ${ }^{*}$ represent statistical significance at the $1 \%, 5 \%$, and $10 \%$ levels, respectively. 


\section{Table 6 \\ Discretionary Accruals on Domestic Pre-tax Income and Pre-tax Foreign Income and Interacted Effects}

Panel A: Full Sample - Profit and Loss Firm-years

\begin{tabular}{|c|c|c|c|c|c|c|}
\hline & Prediction & Model 1 & Model 2 & Model 3 & Model 4 & Model 5 \\
\hline INTERCEPT & & $\begin{array}{l}-0.275^{* * *} \\
(-4.87)\end{array}$ & $\begin{array}{l}-0.528^{* * *} \\
(-8.71)\end{array}$ & $\begin{array}{l}-0.458^{* * *} \\
(-7.63)\end{array}$ & $\begin{array}{l}-0.517^{* * *} \\
(-8.54)\end{array}$ & $\begin{array}{l}-0.441^{* * *} \\
(-7.35)\end{array}$ \\
\hline PIDOM & $(+)$ & $\begin{array}{l}22.031^{* * *} \\
(42.97)\end{array}$ & $\begin{array}{l}27.278^{* * *} \\
(47.96)\end{array}$ & $\begin{array}{l}27.929^{* * *} \\
(50.36)\end{array}$ & $\begin{array}{l}27.374^{* * *} \\
(48.25)\end{array}$ & $\begin{array}{l}27.758^{* * * *} \\
(50.26)\end{array}$ \\
\hline PIFO & $(+)$ & $\begin{array}{l}14.817^{* * *} \\
(15.62)\end{array}$ & $\begin{array}{l}19.078^{* * *} \\
(15.76)\end{array}$ & $\begin{array}{l}18.758^{* * *} \\
(15.37)\end{array}$ & $\begin{array}{l}19.001^{* * *} \\
(15.58)\end{array}$ & $\begin{array}{l}18.867^{* * *} \\
(15.44)\end{array}$ \\
\hline PIDOM*RULE OF LAW & & & & $\begin{array}{l}-8.111^{* * *} \\
(-8.64)\end{array}$ & & $\begin{array}{l}-8.582^{* * *} \\
(-9.28)\end{array}$ \\
\hline PIFO*RULE OF LAW & $(-)$ & & & $\begin{array}{l}-20.788^{* * *} \\
(-10.78)\end{array}$ & & $\begin{array}{l}-20.872^{\text {*** }} \\
(-10.71)\end{array}$ \\
\hline PIDOM*HAVEN INTENSITY & & & & & $\begin{array}{l}10.558^{* * *} \\
(4.25)\end{array}$ & $\begin{array}{l}12.161^{\text {*** }} \\
(5.30)\end{array}$ \\
\hline PIFO*HAVEN INTENSITY & $(+)$ & & & & $\begin{array}{c}-4.357 \\
(-0.93)\end{array}$ & $\begin{array}{l}-2.588 \\
(-0.57)\end{array}$ \\
\hline CONTROLS & & $\mathrm{NO}$ & YES & YES & YES & YES \\
\hline $\mathrm{N}$ & & 11,077 & 11,077 & 11,077 & 11,077 & 11,077 \\
\hline ADJRSQ & & 0.214 & 0.312 & 0.340 & 0.322 & 0.347 \\
\hline PIDOM-PIFO & & $\begin{array}{l}7.215^{* * *} \\
(6.36)\end{array}$ & $\begin{array}{l}8.200^{* * *} \\
(5.71)\end{array}$ & $\begin{array}{l}9.172^{* * *} \\
(6.37)\end{array}$ & $\begin{array}{l}8.373^{* * *} \\
(5.79)\end{array}$ & $\begin{array}{l}8.891^{* * *} \\
(6.18)\end{array}$ \\
\hline
\end{tabular}

Notes: This table presents estimates from Equation (11): PTDACC $i t=\gamma+\pi_{0}$ PIDOM $_{i t}+\pi_{1}$ PIDOM $_{i t} *$ RULE OF LAW Lit $_{2} \pi_{2}$ PIDOM $_{i t} *$ HAVEN INTENSITY $_{i t}+\sum_{k} \pi_{k}$ PIDOM $_{i t} *$ CONTROL $_{i t}^{k}+\omega_{0}$ PIFO $_{i t}+$ $\omega_{1}$ PIFO $_{i t} *$ RULE OF LAW $i t+\omega_{2}$ PIFO $_{i t} *$ HAVEN INTENSITY $i t+\sum_{k} \omega_{k}$ PIFO $_{i t} *$ CONTROL $_{i t}^{k}+e_{i t}$. Each of the variables shown in the table is defined in Table 3. T-statistics, shown in parentheses below the coefficient estimates, are based on standard errors that are clustered by firm and year. One tailed tests of significance are used where a signed prediction has been made. $* * *, * *$, and * represent statistical significance at the $1 \%, 5 \%$, and $10 \%$ levels, respectively. 


\section{Table 6 (continued) \\ Discretionary Accruals on Domestic Pre-tax Income and Pre-tax Foreign Income and Interacted Effects}

Panel B: Sub-sample of Firm-Years with Positive Pre-tax Domestic Income and Positive Pre-tax Foreign Income

\begin{tabular}{|c|c|c|c|c|c|c|}
\hline & Prediction & Model 1 & Model 2 & Model 3 & Model 4 & Model 5 \\
\hline INTERCEPT & & $\begin{array}{l}1.420^{* * *} \\
(15.23)\end{array}$ & $\begin{array}{l}0.793^{* * *} \\
(7.73)\end{array}$ & $\begin{array}{l}0.742^{* * *} \\
(7.20)\end{array}$ & $\begin{array}{l}0.801^{\text {*** }} \\
(7.81)\end{array}$ & $\begin{array}{l}0.762^{* * *} \\
(7.40)\end{array}$ \\
\hline PIDOM & $(+)$ & $\begin{array}{l}5.517^{* * *} \\
(6.80)\end{array}$ & $\begin{array}{l}13.060^{* * *} \\
(14.60)\end{array}$ & $\begin{array}{l}14.207^{* * *} \\
(15.81)\end{array}$ & $\begin{array}{l}13.120^{* * *} \\
(14.66)\end{array}$ & $\begin{array}{l}14.231^{* * *} \\
(15.80)\end{array}$ \\
\hline PIFO & $(+)$ & $\begin{array}{l}4.984^{* * *} \\
(4.12)\end{array}$ & $\begin{array}{l}8.197^{* * *} \\
(4.70)\end{array}$ & $\begin{array}{l}8.779^{* * *} \\
(4.96)\end{array}$ & $\begin{array}{l}7.685^{* * *} \\
(4.43)\end{array}$ & $\begin{array}{l}8.011^{* * *} \\
(4.56)\end{array}$ \\
\hline PIDOM*RULE OF LAW & & & & $\begin{array}{l}-3.915^{* * *} \\
(-2.78)\end{array}$ & & $\begin{array}{l}-3.756^{* * *} \\
(-2.64)\end{array}$ \\
\hline PIFO*RULE OF LAW & $(-)$ & & & $\begin{array}{l}-17.132^{* * *} \\
(-7.13)\end{array}$ & & $\begin{array}{l}-18.974^{* * *} \\
(-7.36)\end{array}$ \\
\hline PIDOM*HAVEN INTENSITY & & & & & $\begin{array}{l}-5.471^{*} \\
(-1.57)\end{array}$ & $\begin{array}{l}-3.458 \\
(-0.97)\end{array}$ \\
\hline PIFO*HAVEN INTENSITY & $(+)$ & & & & $\begin{array}{l}19.885^{* * *} \\
(2.98)\end{array}$ & $\begin{array}{l}19.479^{* * *} \\
(2.93)\end{array}$ \\
\hline CONTROLS & & NO & YES & YES & YES & YES \\
\hline $\mathrm{N}$ & & 6,529 & 6,529 & 6,529 & 6,529 & 6,529 \\
\hline ADJRSQ & & 0.010 & 0.115 & 0.143 & 0.115 & 0.144 \\
\hline PIDOM-PIFO & & $\begin{array}{c}0.533 \\
(0.36)\end{array}$ & $\begin{array}{l}4.863^{* * *} \\
(2.41)\end{array}$ & $\begin{array}{l}5.428^{* * *} \\
(2.67)\end{array}$ & $\begin{array}{l}5.435^{* * *} \\
(2.71)\end{array}$ & $\begin{array}{l}6.220^{* * *} \\
(3.08)\end{array}$ \\
\hline
\end{tabular}

Notes: This table presents estimates from Equation (11): PTDACC $_{i t}=\gamma+\pi_{0}$ PIDOM $_{i t}+\pi_{1}$ PIDOM $_{i t} *$ RULE OF LAW Lt $+\pi_{2}$ PIDOM $_{i t} *$ HAVEN INTENSITY $_{i t}+\sum_{k} \pi_{k}$ PIDOM $_{i t} *$ CONTROL $_{i t}^{k}+\omega_{0}$ PIFO $_{i t}+$ $\omega_{1}$ PIFO $_{i t} *$ RULE OF LAW $i t+\omega_{2}$ PIFO $_{i t} *$ HAVEN INTENSITY $Y_{i t}+\sum_{k} \omega_{k}$ PIFO $_{i t} *$ CONTROL $_{i t}^{k}+e_{i t}$. Only observations with positive foreign and domestic pre-tax incomes are included in the tests. Each of the variables shown in the table is defined in Table 3. T-statistics, shown in parentheses below the coefficient estimates, are based on standard errors that are clustered by firm and year. One tailed tests of significance are used where a signed prediction has been made. ${ }^{* * *},{ }^{* *}$, and $*$ represent statistical significance at the $1 \%, 5 \%$, and $10 \%$ levels, respectively. 
Table 7

Absolute Value of Discretionary Accruals as a Function of Rule of Law, Tax Haven Intensity, and Controls

\begin{tabular}{|c|c|c|c|c|}
\hline & Prediction & Model 1 & Model 2 & Model 3 \\
\hline \multirow[t]{2}{*}{ INTERCEPT } & & $5.664^{* * *}$ & $5.098^{* * *}$ & $5.657^{* * *}$ \\
\hline & & $(11.90)$ & $(17.18)$ & $(11.97)$ \\
\hline \multirow[t]{2}{*}{ RULE OF LAW } & $(-)$ & $-0.306^{* *}$ & & $-0.306^{* *}$ \\
\hline & & $(-2.20)$ & & $(-2.14)$ \\
\hline \multirow[t]{2}{*}{ HAVEN INTENSITY } & $(+)$ & & $0.649^{* * *}$ & $0.649^{* * *}$ \\
\hline & & & $(3.83)$ & $(3.61)$ \\
\hline \multirow[t]{2}{*}{ SPE INTENSITY } & & $0.223^{*}$ & $0.255^{* * *}$ & $0.236^{* *}$ \\
\hline & & $(1.69)$ & $(1.86)$ & $(1.82)$ \\
\hline \multirow[t]{2}{*}{ FOREIGNNESS } & & $0.419^{* * *}$ & $0.383^{* *}$ & $0.380^{* *}$ \\
\hline & & $(3.22)$ & $(2.92)$ & $(2.92)$ \\
\hline \multirow[t]{2}{*}{ NCOUNTRIES } & & $-0.079^{*}$ & -0.038 & $-0.078^{*}$ \\
\hline & & $(-2.12)$ & $(-1.06)$ & $(-2.11)$ \\
\hline \multirow[t]{2}{*}{ SIZE } & & $-0.190^{* * *}$ & $-0.188^{* * *}$ & $-0.197^{* * *}$ \\
\hline & & $(-8.83)$ & $(-8.55)$ & $(-8.98)$ \\
\hline \multirow[t]{2}{*}{ CPI CHANGE SUB COUNTRIES } & & $-0.002^{* *}$ & -0.001 & $-0.001^{*}$ \\
\hline & & $(-2.37)$ & $(-0.83)$ & $(-1.97)$ \\
\hline \multirow[t]{2}{*}{ GDP CHANGE SUB COUNTRIES } & & $-0.190^{* *}$ & $-0.173^{* *}$ & $-0.198^{* *}$ \\
\hline & & $(-2.82)$ & $(-2.84)$ & $(-2.95)$ \\
\hline \multirow[t]{2}{*}{ SALES VOLATILITY } & & $1.406^{* * *}$ & $1.388^{* * *}$ & $1.399^{* * *}$ \\
\hline & & $(6.85)$ & $(6.67)$ & $(6.70)$ \\
\hline \multirow[t]{2}{*}{ CASH FLOW VOLATILITY } & & $11.276^{* * *}$ & $10.845^{* * *}$ & $10.948^{* * *}$ \\
\hline & & $(11.26)$ & $(10.64)$ & $(10.77)$ \\
\hline $\mathrm{N}$ & & 11,077 & 11,077 & 11,077 \\
\hline ADJRSQ & & 0.097 & 0.096 & 0.098 \\
\hline
\end{tabular}

Notes: This table presents estimates from the following model: $\mid$ PTDACC $\left.\right|_{i t}=\alpha_{0}+\alpha_{1}$ HAVEN INTENSITY $_{i t}+$ $\alpha_{2}$ RULE OF LAW $W_{i t}+\sum \alpha_{k}$ CONTROL $_{i t}^{k}+\epsilon_{i t}$. Each of the variables shown in the table is defined in Table 3. Tstatistics, shown in parentheses below the coefficient estimates, are based on standard errors that are clustered by firm and year. One tailed tests of significance are used where a signed prediction has been made. ***, **, and * represent statistical significance at the $1 \%, 5 \%$, and $10 \%$ levels, respectively. 


\section{Table 8}

Absolute Value of Discretionary Accruals on Pre-tax Domestic Income and Pre-tax Foreign Income and Interacted Effects

\begin{tabular}{|c|c|c|c|c|c|c|}
\hline & Prediction & Model 1 & Model 2 & Model 3 & Model 4 & Model 5 \\
\hline INTERCEPT & & $\begin{array}{l}3.407^{* * *} \\
(78.01)\end{array}$ & $\begin{array}{l}3.625^{* * *} \\
(70.25)\end{array}$ & $\begin{array}{l}3.579^{* * *} \\
(69.73)\end{array}$ & $\begin{array}{l}3.592^{* * *} \\
(70.03)\end{array}$ & $\begin{array}{l}3.584^{* * *} \\
(69.92)\end{array}$ \\
\hline |PIDOM| & $(+)$ & $\begin{array}{l}8.913^{* * *} \\
(21.53)\end{array}$ & $\begin{array}{l}6.984^{* * * *} \\
(14.13)\end{array}$ & $\begin{array}{l}7.776^{* * *} \\
(15.88)\end{array}$ & $\begin{array}{l}7.624^{* * *} \\
(15.55)\end{array}$ & $\begin{array}{l}7.853^{* * *} \\
(16.03)\end{array}$ \\
\hline |PIFO| & $(+)$ & $\begin{array}{l}4.215^{* * *} \\
(7.13)\end{array}$ & $\begin{array}{l}4.363^{* * *} \\
(4.81)\end{array}$ & $\begin{array}{l}4.723^{* * *} \\
(5.20)\end{array}$ & $\begin{array}{l}4.080^{* * *} \\
(4.47)\end{array}$ & $\begin{array}{l}4.309^{* * *} \\
(4.77)\end{array}$ \\
\hline $\mid$ PIDOM| *RULE OF LAW & & & & $\begin{array}{l}-0.821 \\
(-1.11)\end{array}$ & & $\begin{array}{l}-0.876 \\
(-1.17)\end{array}$ \\
\hline $\mid$ PIFO | *RULE OF LAW & $(-)$ & & & $\begin{array}{l}-5.956^{* * *} \\
(-4.35)\end{array}$ & & $\begin{array}{l}-7.090^{* * *} \\
(-5.24)\end{array}$ \\
\hline $\mid$ PIDOM| *HAVEN INTENSITY & & & & & $\begin{array}{c}1.275 \\
(0.78)\end{array}$ & $\begin{array}{l}1.437 \\
(0.90)\end{array}$ \\
\hline $\mid$ PIFO | *HAVEN INTENSITY & $(+)$ & & & & $\begin{array}{l}10.759^{* * *} \\
(3.52)\end{array}$ & $\begin{array}{l}13.998^{* * *} \\
(4.55)\end{array}$ \\
\hline CONTROLS & & NO & YES & YES & YES & YES \\
\hline $\mathrm{N}$ & & 11,077 & 11,077 & 11,077 & 11,077 & 11,077 \\
\hline ADJRSQ & & 0.057 & 0.155 & 0.147 & 0.148 & 0.151 \\
\hline PIDOM-PIFO & & $\begin{array}{l}4.699^{* * *} \\
(6.10)\end{array}$ & $\begin{array}{l}2.620^{* * *} \\
(2.46)\end{array}$ & $\begin{array}{l}3.053^{* * *} \\
(2.88)\end{array}$ & $\begin{array}{l}3.543^{* * *} \\
(3.33)\end{array}$ & $\begin{array}{l}3.545^{* * *} \\
(3.36)\end{array}$ \\
\hline $\begin{array}{l}\text { Notes: This table presents estimate } \\
R U L E O F L A W_{i t}+\pi_{2}|P I D O M|_{i t} \\
\omega_{1}|P I F O|_{i t} * R U L E O F L A W_{i t}+c \\
\text { of the variables shown in the table } \\
\text { estimates, are based on standard err } \\
\text { where a signed prediction has been } \\
\text { levels, respectively. }\end{array}$ & $\begin{array}{l}\text { es from the } \\
* H A V E N I \\
\omega_{2}|P I F O|_{i t} \\
\text { is defined ir } \\
\text { rors that are } \\
\text { made. }{ }^{* * *} \text {, }\end{array}$ & $\begin{array}{l}\text { owing mo } \\
\text { ENSITY } \\
\text { IAVEN IN } \\
\text { able 3. T-s } \\
\text { stered by } \\
\text {, and * re }\end{array}$ & $\begin{array}{l}: \mid P T D A C \\
\sum_{k} \pi_{k} \mid P I D \\
N S I T Y_{i t} \\
\text { istics, sho } \\
m \text { and year } \\
\text { sent statist }\end{array}$ & $\begin{array}{l}=\gamma+\pi_{0} \\
\left.1\right|_{i t} * C O N \\
{ }_{k} \omega_{k} \mid P I F O \\
\text { n parenthe } \\
\text { ne tailed te }\end{array}$ & $\begin{array}{l}\left.I D O M\right|_{i t}+ \\
O L_{i t}^{k}+\omega_{0} \mid \\
* C O N T R \\
\text { below the } \\
\text { of signific }\end{array}$ & $\begin{array}{l}|P I D O M|_{i t} * \\
\left.F O\right|_{i t}+ \\
i t+e_{i t} . \text { Each } \\
\text { efficient } \\
\text { ce are used } \\
\text {, and } 10 \%\end{array}$ \\
\hline
\end{tabular}


Table 9

Restatement Firm-years as a Function of Rule of Law, Tax Haven Intensity, and Controls

\begin{tabular}{|c|c|c|}
\hline & Prediction & Restatement Year \\
\hline \multirow[t]{2}{*}{ INTERCEPT } & & $-3.251^{* * *}$ \\
\hline & & $(17.78)$ \\
\hline \multirow[t]{2}{*}{ RULE OF LAW } & $(-)$ & $-0.591^{* *}$ \\
\hline & & $(6.29)$ \\
\hline \multirow[t]{2}{*}{ HAVEN INTENSITY } & $(+)$ & -0.094 \\
\hline & & $(0.02)$ \\
\hline \multirow[t]{2}{*}{ SPE INTENSITY } & & $0.923^{* * *}$ \\
\hline & & $(13.59)$ \\
\hline \multirow[t]{2}{*}{ FOREIGNNESS } & & $0.715^{*}$ \\
\hline & & $(3.76)$ \\
\hline \multirow[t]{2}{*}{ NCOUNTRIES } & & 0.156 \\
\hline & & $(1.28)$ \\
\hline \multirow[t]{2}{*}{ SIZE } & & 0.075 \\
\hline & & $(1.22)$ \\
\hline \multirow[t]{2}{*}{ CPI CHANGE SUB COUNTRIES } & & $-0.123^{* * *}$ \\
\hline & & $(6.98)$ \\
\hline \multirow[t]{2}{*}{ GDP CHANGE SUB COUNTRIES } & & -0.104 \\
\hline & & $(1.57)$ \\
\hline \multirow[t]{2}{*}{ SALES VOLATILITY } & & $0.769^{* * *}$ \\
\hline & & $(7.68)$ \\
\hline \multirow[t]{2}{*}{ CASH FLOW VOLATILITY } & & -1.830 \\
\hline & & $(1.45)$ \\
\hline Additional Controls & & Yes \\
\hline $\mathrm{N}$ & & 6,699 \\
\hline Pseudo RSQ & & 0.012 \\
\hline
\end{tabular}

Notes: This table presents results from a logistic regression where the dependent variable is one for firm-years where financial statements were restated. The independent variables shown in the table are described in Table 3. Additional control variables are included, but not presented (see footnote 22). Chi-square statistics, shown in parentheses below the coefficient estimates, are based on standard errors that are clustered by firm and year. ***, **, and * represent statistical significance at the $1 \%, 5 \%$, and $10 \%$ levels, respectively. 


\section{Table 10 \\ Propensity Score Test of Rule of Law on Restatements}

Panel A: Frequency of Restatement Firm-years Across Strong and Weak RULE OF LAW

\begin{tabular}{lcc} 
& Strong RULE OF LAW & Weak RULE OF LAW \\
\hline Did not Restate & 1,050 & 1,005 \\
Restated & 12 & 57 \\
\hline Total & 1,062 & 1,062 \\
\hline Chi-Square & 30.330 & \\
Prob Chi-Square $=0$ & $<.0001$ & \\
\hline
\end{tabular}

Notes: This table shows the frequency of restatement of firm-years in weak RULE OF LAW countries relative to a matched sample of firm-years in strong RULE OF LAW countries. Firm-years are matched based on their propensity to have weak RULE OF LAW - defined as being in the lowest quintile of RULE OF LAW. Control firm-years are drawn from the highest two quintiles of RULE OF LAW. 


\section{Table 10 (continued) \\ Propensity Score Test of Rule of Law on Restatements}

Panel B: Test of the Propensity Score Match Quality

\begin{tabular}{|c|c|c|c|c|c|}
\hline \multirow[t]{2}{*}{ 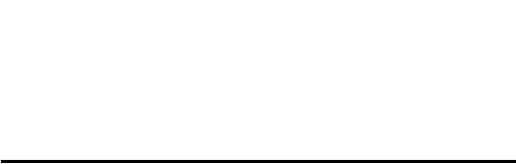 } & & \multicolumn{2}{|c|}{ MEAN } & \multicolumn{2}{|c|}{ T-TEST } \\
\hline & & $\begin{array}{c}\text { Weak RULE } \\
\text { OF LAW }\end{array}$ & $\begin{array}{l}\text { Strong } R U L E \\
\text { OF LAW }\end{array}$ & $\mathbf{T}$ & Prob T \\
\hline RULE OF LAW & Pre-match & 0.372 & 1.503 & -123.16 & 0.000 \\
\hline RULE OF LAW & Post-match & 0.372 & 1.371 & - 90.10 & 0.000 \\
\hline HAVEN INTENSITY & Pre-match & 0.203 & 0.167 & 5.27 & 0.000 \\
\hline HAVEN INTENSITY & Post-match & 0.203 & 0.198 & 0.58 & 0.561 \\
\hline SPE INTENSITY & Pre-match & 0.055 & 0.040 & 2.48 & 0.013 \\
\hline SPE INTENSITY & Post-match & 0.055 & 0.068 & - 1.05 & 0.294 \\
\hline FOREIGNNESS & Pre-match & 0.376 & 0.339 & 4.77 & 0.000 \\
\hline FOREIGNNESS & Post-match & 0.376 & 0.393 & - 1.81 & 0.070 \\
\hline NCOUNTRIES & Pre-match & 2.643 & 1.975 & 20.26 & 0.000 \\
\hline NCOUNTRIES & Post-match & 2.643 & 2.502 & 3.44 & 0.001 \\
\hline SIZE & Pre-match & 7.636 & 6.324 & 22.01 & 0.000 \\
\hline SIZE & Post-match & 7.636 & 7.438 & 2.83 & 0.005 \\
\hline CPI CHANGE SUB COUNTRIES & Pre-match & 7.994 & 2.371 & 30.79 & 0.000 \\
\hline CPI CHANGE SUB COUNTRIES & Post-match & 7.994 & 7.382 & 2.06 & 0.040 \\
\hline GDP CHANGE SUB COUNTRIES & Pre-match & 3.759 & 3.003 & 13.10 & 0.000 \\
\hline GDP CHANGE SUB COUNTRIES & Post-match & 3.759 & 3.589 & 2.30 & 0.022 \\
\hline SALES VOLATILITY & Pre-match & 0.198 & 0.250 & - 6.47 & 0.000 \\
\hline SALES VOLATILITY & Post-match & 0.198 & 0.190 & 0.98 & 0.325 \\
\hline CASH FLOW VOLATILITY & Pre-match & 0.049 & 0.066 & - 8.41 & 0.000 \\
\hline CASH FLOW VOLATILITY & Post-match & 0.049 & 0.046 & 2.23 & 0.026 \\
\hline
\end{tabular}

Notes: This table evaluates the effectiveness of the matches pre-match versus post-match. The first row of each variable shows the mean value before matches have been assigned, and the right two columns test whether treatment and control samples are different. The second row repeats the exercise after the matches are made. 


\section{Table 11}

\section{Propensity Score Test of Haven Intensity on Restatements}

Panel A: Frequency of Restatement Firm-years Across Strong and Weak HAVEN INTENSITY

\begin{tabular}{lcc} 
& Strong HAVEN INTENSITY & Weak HAVEN INTENSITY \\
\hline Did not Restate & 1,335 & 1,318 \\
Restated & 45 & 62 \\
\hline Total & 1,380 & 1,380 \\
\hline Chi-Square & 2.490 & \\
Prob Chi-Square $=0$ & 0.115 & \\
\hline
\end{tabular}

Notes: This table shows the frequency of restatement of firm-years with weak HAVEN INTENSITY relative to a matched sample of firm-years with strong HAVEN INTENSITY. Firm-years are matched based on their propensity to have weak HAVEN INTENSITY - defined as being in the lowest quintile of HAVEN INTENSITY. Control firm-years are drawn from the highest two quintiles of HAVEN INTENSITY. 


\section{Table 11 (continued) \\ Propensity Score Test of Haven Intensity on Restatements}

Panel B: Test of the Propensity Score Match Quality

\begin{tabular}{|c|c|c|c|c|c|}
\hline & & \multicolumn{2}{|c|}{ MEAN } & \multicolumn{2}{|c|}{ T-TEST } \\
\hline & & $\begin{array}{c}\text { Strong } \\
\text { HAVEN } \\
\text { INTENSITY }\end{array}$ & $\begin{array}{c}\text { Weak } \\
\text { HAVEN } \\
\text { INTENSITY }\end{array}$ & $\mathrm{T}$ & Prob T \\
\hline HAVEN INTENSITY & Pre-match & 0.453 & 0.032 & 117.88 & 0.000 \\
\hline HAVEN INTENSITY & Post-match & 0.453 & 0.038 & 81.95 & 0.000 \\
\hline RULE OF LAW & Pre-match & 1.073 & 1.157 & - 4.88 & 0.000 \\
\hline RULE OF LAW & Post-match & 1.073 & 1.033 & 1.91 & 0.056 \\
\hline SPE INTENSITY & Pre-match & 0.037 & 0.048 & - 2.17 & 0.030 \\
\hline SPE INTENSITY & Post-match & 0.037 & 0.046 & -1.62 & 0.105 \\
\hline FOREIGNNESS & Pre-match & 0.368 & 0.328 & 5.70 & 0.000 \\
\hline FOREIGNNESS & Post-match & 0.368 & 0.376 & - 0.94 & 0.348 \\
\hline NCOUNTRIES & Pre-match & 2.099 & 1.943 & 5.54 & 0.000 \\
\hline NCOUNTRIES & Post-match & 2.643 & 2.130 & - $\quad 0.94$ & 0.347 \\
\hline SIZE & Pre-match & 6.388 & 6.263 & 2.11 & 0.000 \\
\hline SIZE & Post-match & 6.388 & 6.437 & - 0.70 & 0.005 \\
\hline CPI CHANGE SUB COUNTRIES & Pre-match & 3.697 & 4.040 & - 3.79 & 0.000 \\
\hline CPI CHANGE SUB COUNTRIES & Post-match & 3.697 & 3.954 & -1.33 & 0.040 \\
\hline GDP CHANGE SUB COUNTRIES & Pre-match & 3.607 & 3.136 & 8.82 & 0.000 \\
\hline GDP CHANGE SUB COUNTRIES & Post-match & 3.607 & 3.628 & - 0.31 & 0.022 \\
\hline SALES VOLATILITY & Pre-match & 0.286 & 0.225 & 3.86 & 0.000 \\
\hline SALES VOLATILITY & Post-match & 0.286 & 0.281 & 0.34 & 0.325 \\
\hline CASH FLOW VOLATILITY & Pre-match & 0.075 & 0.063 & 5.24 & 0.000 \\
\hline CASH FLOW VOLATILITY & Post-match & 0.075 & 0.072 & 1.11 & 0.265 \\
\hline
\end{tabular}

Notes: This table evaluates the effectiveness of the matches pre-match vs post-match. The first row of each variable shows the mean value before matches are assigned, and the right two columns test whether treatment and control samples are different. The second row repeats the exercise after the matches are made. 
Figure 1

Plot of the Effect of RULE OF LAW and HAVEN INTENSITY on Discretionary Accruals (PTDACC)

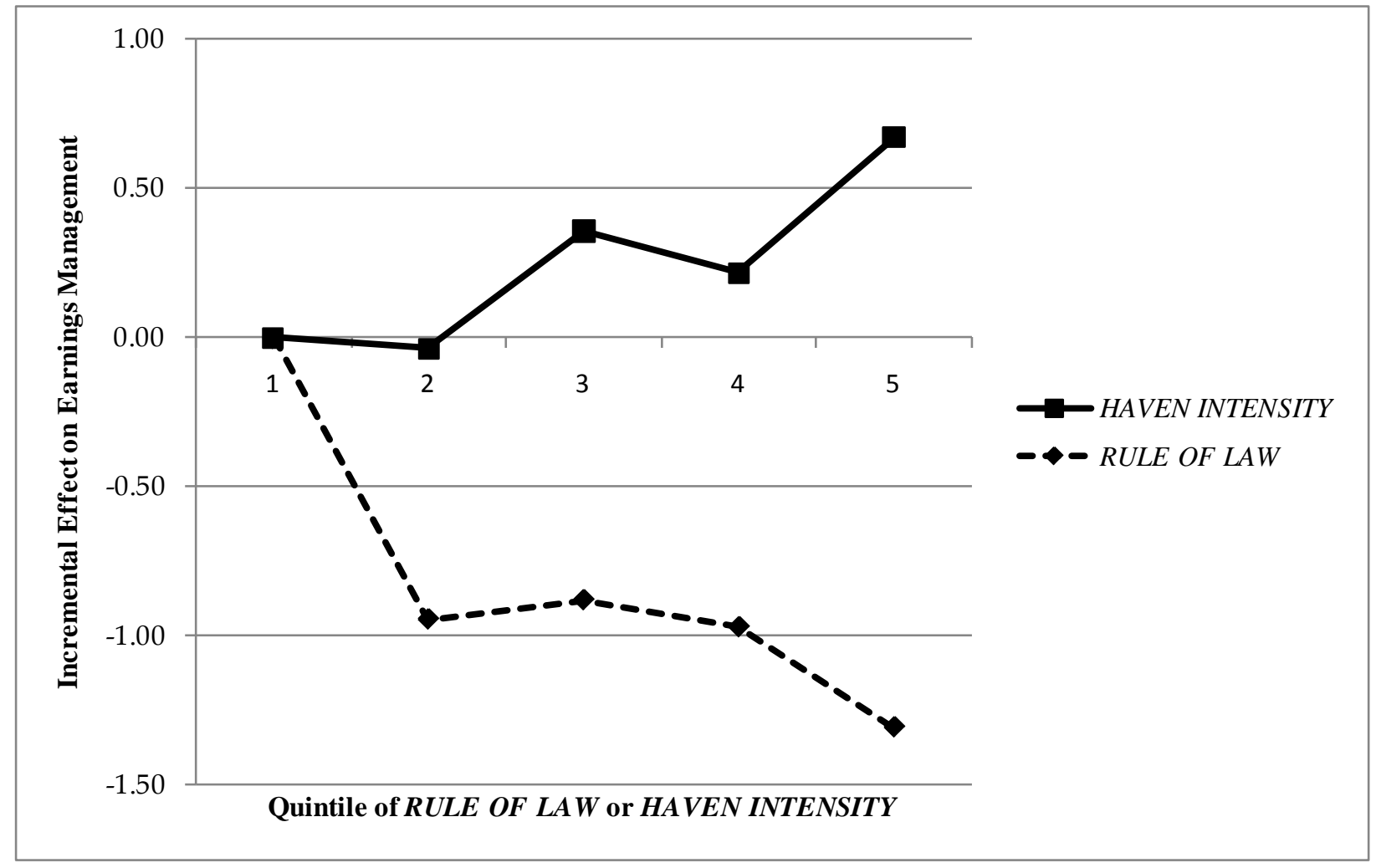

Notes: This figure presents estimates of the effect of RULE OF LAW and HAVEN INTENSITY on discretionary accruals (PTDACC) when both foreign and domestic pre-tax earnings are positive. The estimates are obtained by estimating Equation (3), except replacing the continuous measures of RULE OF LAW (HAVEN INTENSITY) with 5 indicator variables based on quintiles of RULE OF LAW (HAVEN INTENSITY). To show the incremental effect, the baseline is centered on zero. 
Figure 2

Plot of the Effect of RULE OF LAW and HAVEN INTENSITY on the Mapping of Pre-tax Income from Foreign Operations (PIFO) into Discretionary Accruals (PTDACC)

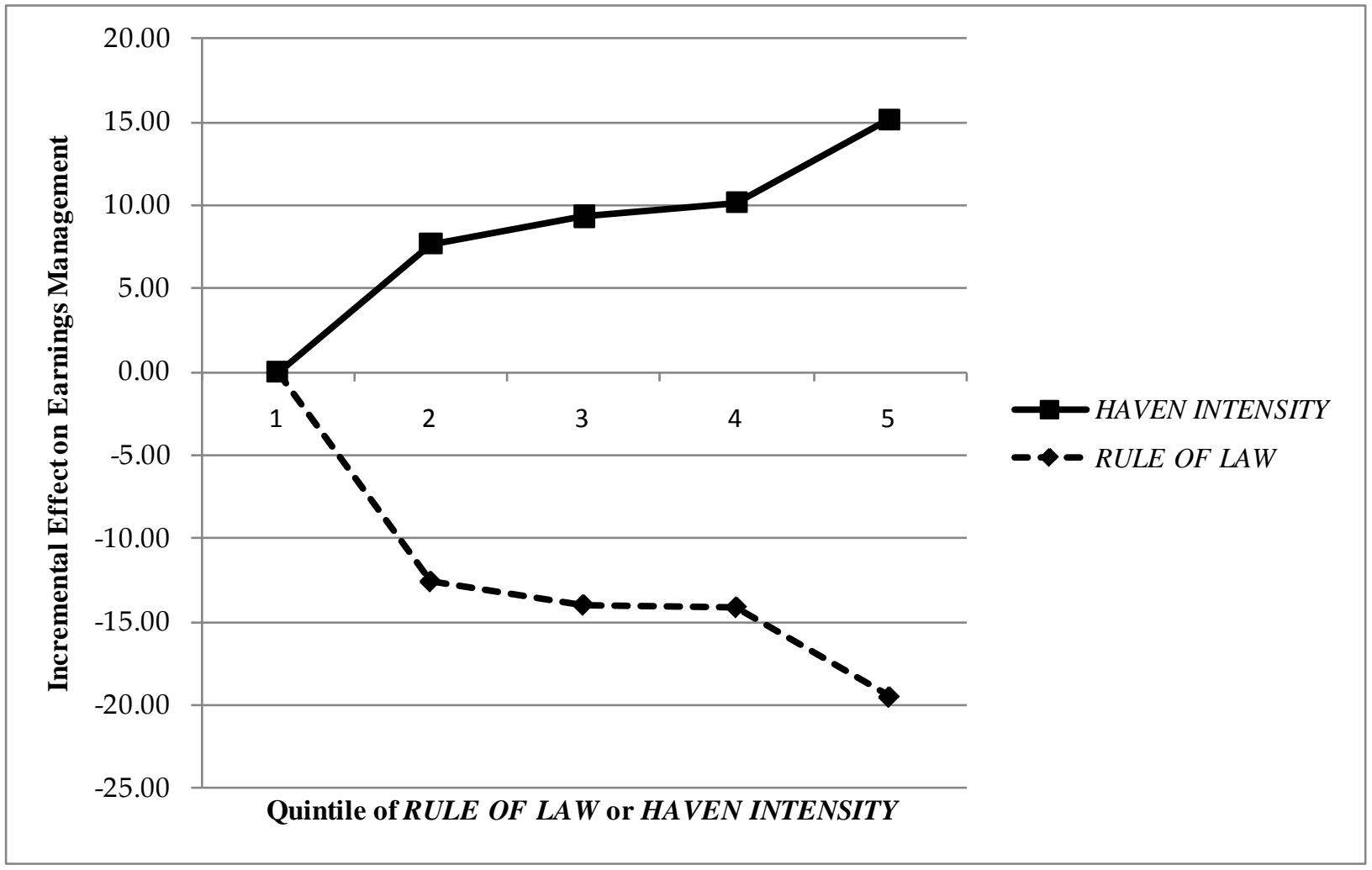

Notes: This figure presents estimates of the effect of RULE OF LAW and HAVEN INTENSITY on the mapping of pre-tax income from foreign operations PIFO into discretionary accruals (PTDACC) when both foreign and domestic pre-tax earnings are positive. The estimates are obtained by estimating Equation (11), except replacing the continuous measures of RULE OF LAW (HAVEN INTENSITY) with 5 indicator variables based on quintiles of RULE OF LAW (HAVEN INTENSITY). To show the incremental effect, the baseline is centered on zero. 